\title{
Behavioral Finance Research in 2020: Cui Bono et Quo Vadis?
}

\author{
Katharina Fischer*,1, Othmar M Lehner ${ }^{2}$ \\ ${ }^{1}$ University of Applied Sciences Upper Austria \\ ${ }^{2}$ Hanken Schools of Economics, Helsinki, Finland
}

\section{ARTICLE INFO}

\section{Article history:}

Received 30 May 2019

Revised 20 October 2020 and 05

January 2021

Accepted 10 March 2021

Published 23 March 2021

\section{Keywords:}

Behavioral Finance

Neurofinance

Limits to Arbitrage

Market Anomalies

Behavioral Biases

\author{
ABSTRACT
}

\begin{abstract}
Emanating from the influential survey of Barberis and Thaler (2003), this systematic literature review examines the significant volume of studies on behavioral finance from 36 reputable finance journals published be-tween 2009 and 2019. The findings are clustered into eight prominent research streams, which indicate the current developments in behavioral finance. Findings show that research intensively focuses on behavioral biases and their influence on economic phenomena. Driven by the impetus to understand the human mind, significant findings originated in the relatively new field of Neurofinance. Additionally, the analysis addresses the influence of market sentiment and its correlation with some of the other findings. Furthermore, implications on the limits to arbitrage in connection with some financial anomalies complete the holistic picture.
\end{abstract}

\section{Introduction}

Market efficiency and investor behavior have always been a driving force behind behavioral finance research. Originating from the traditional theory of efficient markets, several pioneers achieved valuable research breakthroughs (Fama, 1970; Samuelson, 1965; Shleifer \& Vishny, 1997). Nonetheless, the omnipresent uncertainty in financial markets guided the researchers' focus on more psychology-based approaches. Barberis and Thaler (2003) laid the foundation for behavioral finance by publishing an extensive survey of behavioral finance and its implications. Thenceforth, many other researchers followed, investigating the interconnectedness of psychological and emotional factors in financial markets. There is an extensive body of literature on different aspects of behavioral finance, yet to the best of our knowledge, no publication introduces a holistic survey of the plethora of studies on behavioral finance. Driven by the demand to understand the interconnectedness between psychology and financial theories and to provide a comprehensive view of the development of behavioral finance, this paper aims to provide a systematic literature review.

Researchers have investigated different aspects of behavioral finance. Barberis and Thaler (2003) inform readers about those studies focusing on different biases such as conservatism, overconfidence, representativeness, and its influence on the investors' unconscious decision making. Today, the most influential research streams focus on cognitive and emotional biases (Sahi, Arora, \& Dhameja, 2013). Within research on behavioral biases, there are two main strands, those who approach behavioral biases and their influence on the market holistically (Gokhale, Tremblay, \& Tremblay, 2015; Korniotis \& Kumar, 2011; Wei, 2018), and those who instead focus on one specific bias at a time, such as the anchoring bias (Anderson \& Zastawniak, 2016) or the confirmation bias (Duong, Pescetto, \& Santamaria, 2012). Embedded within the research on behavioral biases, the disposition effect has gained prominence since Barber-is and Thaler's survey. The effect has been critically revisited with the focus on gender

* Corresponding author.

E-Mail address: katharina.a.fischer@gmail.com 
(Durand, Fung, \& Limkriangkrai, 2019; Meziani \& Noma, 2018), maturity (Cheng, Lee, \& Lin, 2013; Kubińska, Markiewicz, \& Tyszka, 2012), and personality traits (Cecchini, Bajo, Russo, \& Sobrero, 2019). Besides the wellknown focal points within research in behavioral finance, such as herding behavior, risk perception, or cognitive dissonance, a relatively new field has emerged, namely, that focusing on the influence of the (news) media on financial markets (Peress, 2014). Next to the increase in information transparency (Fan, Talavera, \& Tran, 2019), social media platforms, such as Twitter, can also threaten the price development of specific securities through the spread of fake information, which might negatively impact the investors' price perception (Reed, 2016). Furthermore, a new line of investigation has considered the so-called calendar effects such as the January effect, Halloween effect, or Monday effect (Chen \& Daves, 2018; Urquhart \& McGroarty, 2014) as well as weather conditions (Goetzmann, Kim, Kumar, \& Wang, 2015; Kim, 2017) and their impact on trading volume and asset pricing. The evidence further suggests a strong connection of such effects with market sentiment.

The overall aim of behavioral finance is to predict future stock market returns and explain occurred mispricing. New findings help explain economic phenomena such as the momentum effects (Galariotis, Holmes, Kallinterakis, \& Ma, 2014; Hao, Chou, Ko, \& Yang, 2018), post-earnings-announcement-drift (Yan \& Zhao, 2018), and the MAXeffect (Bali, Cakici, \& White-law, 2011), all of which are elicited by behavioral biases. To reiterate, the importance is attributed to the influence of cognitive factors and emotions on the decision-making process with extensive economic consequences (Barberis \& Thaler, 2003). It is, therefore, necessary to embed psychological and emotional proxies in finance models. A breakthrough in research was the birth of Neurofinance as a subfield of behavioral finance. Its insights facilitate the development of economic models with the support of neurosciences and psychology, which jointly shed light on the human mind and behavior (Cheng, 2014; Taffler, 2017).

Lastly, it was pertinent, for present purposes, to browse through literature revisiting the limits to arbitrage. Shleifer and Vishny (1997) already extensively researched this topic. Various anomalies have been associated with limits to arbitrage, such as the asset growth anomaly (Lam \& Wei, 2011) and the turnover anomaly (Chou, Huang, \& Yang, 2013). Extensive research has been carried out within the field of behavioral finance. Therefore, this systematic literature review aims to provide a bird's eye view of the developments within this vibrant field. The goal with this is to determine patterns and paradoxes emerging from the past ten years of research. For this, a keyword search was carried out in articles published since 2009 in 36 prominent finance journals. Consequently, eight salient streams of research were identified, with each contributing to the holistic framework of current financial behavior research.

\section{Research Methodology}

A systematic literature review (SLR) is a systematic and comprehensive process of evaluating and analyzing data to minimize bias (Tranfield, Denyer, \& Smart, 2003) and identify articles providing evidence-based recommendations (Aguinis, Ramani, \& Alabduljader, 2018). According to Tranfield et al. (2003), an SLR is a three-step process, which comprises (1) planning the review, (2) conducting it, and (3) reporting on and disseminating the results. As shown in Figure 1, the six-step approach proposed by Anguinis et al. (2007) was followed.

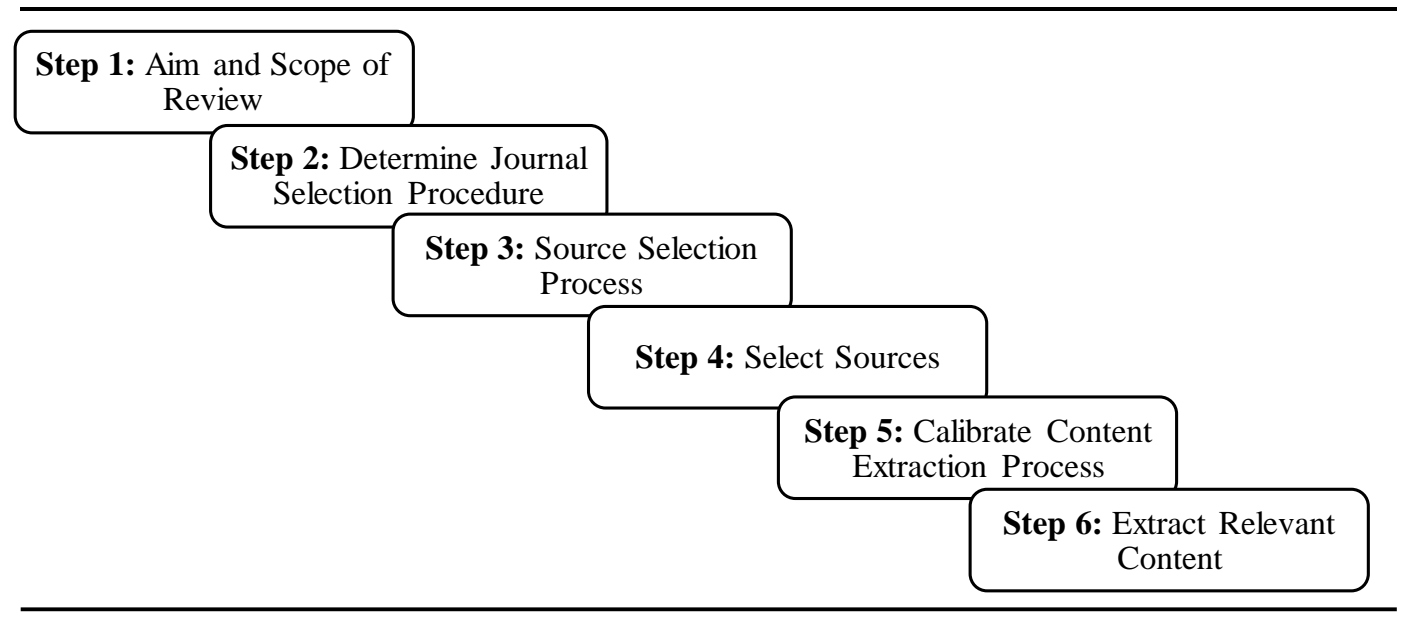

Figure 1. Six-Step Model by Anguinis, Ramani, \& Alabduljader, 2018 


\section{The Three-Step Systematic Literature Review}

This literature review aimed to evaluate the most salient strands of research and their interconnectedness with the field of behavioral finance at large. First, the relevant and clearly delineated research questions were formulated, which this systematic search hopes to answer (Burgers et al. 2019):

RQ1. Are there any patterns or paradoxes in the current state of research?

RQ2. Can a holistic behavioral finance theory yet be identified?

RQ3. What is the trajectory within the current state of research in behavioral finance?

The selection of articles was based on preliminary research in the field, which led to creating a set of clear inclusion criteria. After that, the search was limited based on the year of publication, the source type, publication stage, Academic Journal Guide (AJG) rating, and stipulated search terms. The systematic search was defined through selected keywords and related terms. To enable a holistic evaluation of the development of behavioral finance research, all journals from the respective finance category that were listed in the AJG 2018 with a ranking of three or higher were included. The only exception was including the Journal of Behavioral Finance with an AJG 2018 ranking of two, considering its high relevance for the studied topic. The data ranged between 2009 and 2019 to ensure that it revealed the recent developments in research. All included articles had evidence-based recommendations as part of their analytical work, empirical data, or both (Aguinis et al., 2018). Upon determining the search criteria, search strings were defined, and the appropriate search engine was identified for locating and appraising as much relevant literature as possible. Based on the pre-defined keywords and terms, we created search strings for our databank search. Five different search strings using Boolean operators were used to ensure that the identified papers adopted varied nomenclature. The search was specified by incorporating defined specifications as the time frame and selected finance journals with specific ratings. Finally, only journal articles in the publication stage "final" were included in the search. To conduct an interdisciplinary, systematic literature review, a computerized search of the literature was carried out through Scopus as the selected databank search engine. The outcome of the databank search is listed in the Appendix.

The impact factor is a scientometric index that reflects the frequency with which an average article in a journal was cited in a particular year and is thus frequently used as a proxy for the relative importance of a journal within its field. Therefore, the importance of the findings can be calculated by establishing the number of articles in each journal instead of the total number of findings and then weighting that number by the impact factor.

Table 1. Keywords and corresponding terms for databank search

\begin{tabular}{ll}
\hline Keyword & Including \\
\hline Behavioral Finance & Behavioral Economics, Emotional Finance, Predictability \\
Investors Behavior & $\begin{array}{l}\text { Overconfidence, Investor Confidence, Investor Sentiment, } \\
\text { Mood, Noise Trader, Herding, Rationality }\end{array}$ \\
Limits to Arbitrage & Arbitrageur, Rational Traders, Equilibrium \\
Market Anomalies & Mispricing, Return Anomalies, Market Inefficiency \\
Behavioral Biases & Cognitive Dissonance, Neurofinance \\
\hline
\end{tabular}

The first broad-ranging search elicited 2,969 journal articles, including duplicates due to the different search terms' overlap. Next, the duplicated articles were eliminated, upon which 2,472 articles remained. Thereafter, the first analysis of content was conducted through title screening, which resulted in filtering out articles that did not adhere to the inclusion criteria or did not provide answers to the research questions. The significance of the remaining 609 articles was assessed through abstract screening. Following this step, 213 journal articles remained, with an additional four identified via relevant citations.

The last step of this protocol was the quality assessment of the remaining articles, upon which ultimately 149 remained. 
Table 2. shows the distribution of 149 articles per journal. The impact factor was available for 23 journals. For one article and one discussion paper, no impact factor could be determined. The weighted average of the impact factor based on the collected articles per journal is 3.778 .

Table 2. Distribution of used articles by journal incl. impact factor

\begin{tabular}{|c|c|c|}
\hline Journal & $\begin{array}{l}\text { No. Of } \\
\text { Articles used }\end{array}$ & IF \\
\hline Journal of Behavioral Finance & 38 & 0.581 \\
\hline International Review of Financial Analysis & 14 & 0.782 \\
\hline Journal of Banking and Finance & 14 & 1.599 \\
\hline Journal of Finance & 11 & 17.973 \\
\hline Journal of Financial Economics* & 10 & 13.636 \\
\hline European Journal of Finance & 8 & 0.533 \\
\hline Journal of Empirical Finance & 7 & 1.072 \\
\hline Review of Finance Studies & 7 & 12.516 \\
\hline European Financial Management & 5 & 0.618 \\
\hline Financial Analysts Journal & 5 & 0.92 \\
\hline Journal of Financial Research & 5 & 0.76 \\
\hline Review of Finance (formerly European Finance Review) & 5 & 3.465 \\
\hline Financial Management & 3 & 1.262 \\
\hline Journal of Financial Markets & 3 & 1.033 \\
\hline Financial Review & 2 & 0.567 \\
\hline Journal of Future Markets & 2 & 0.829 \\
\hline Review of Quantitative Finance and Accounting & 2 & 0.65 \\
\hline Annual Review of Financial Economics & 1 & 4.584 \\
\hline Journal of Corporate Finance & 1 & 1.748 \\
\hline Journal of Financial and Quantitative Analysis & 1 & 3.986 \\
\hline Journal of Financial Intermediation & 1 & 3.514 \\
\hline Journal of International Financial Markets Institutions and Money & 1 & 0.956 \\
\hline American Economic Review* & 1 & 11.889 \\
\hline Total & 147 & 3.778 \\
\hline FRB International Finance Discussion Paper No. 1147* & 1 & no IF \\
\hline Journal of Economics and Behavioral Studies* & 1 & no IF \\
\hline
\end{tabular}

*includes articles from relevant citations 


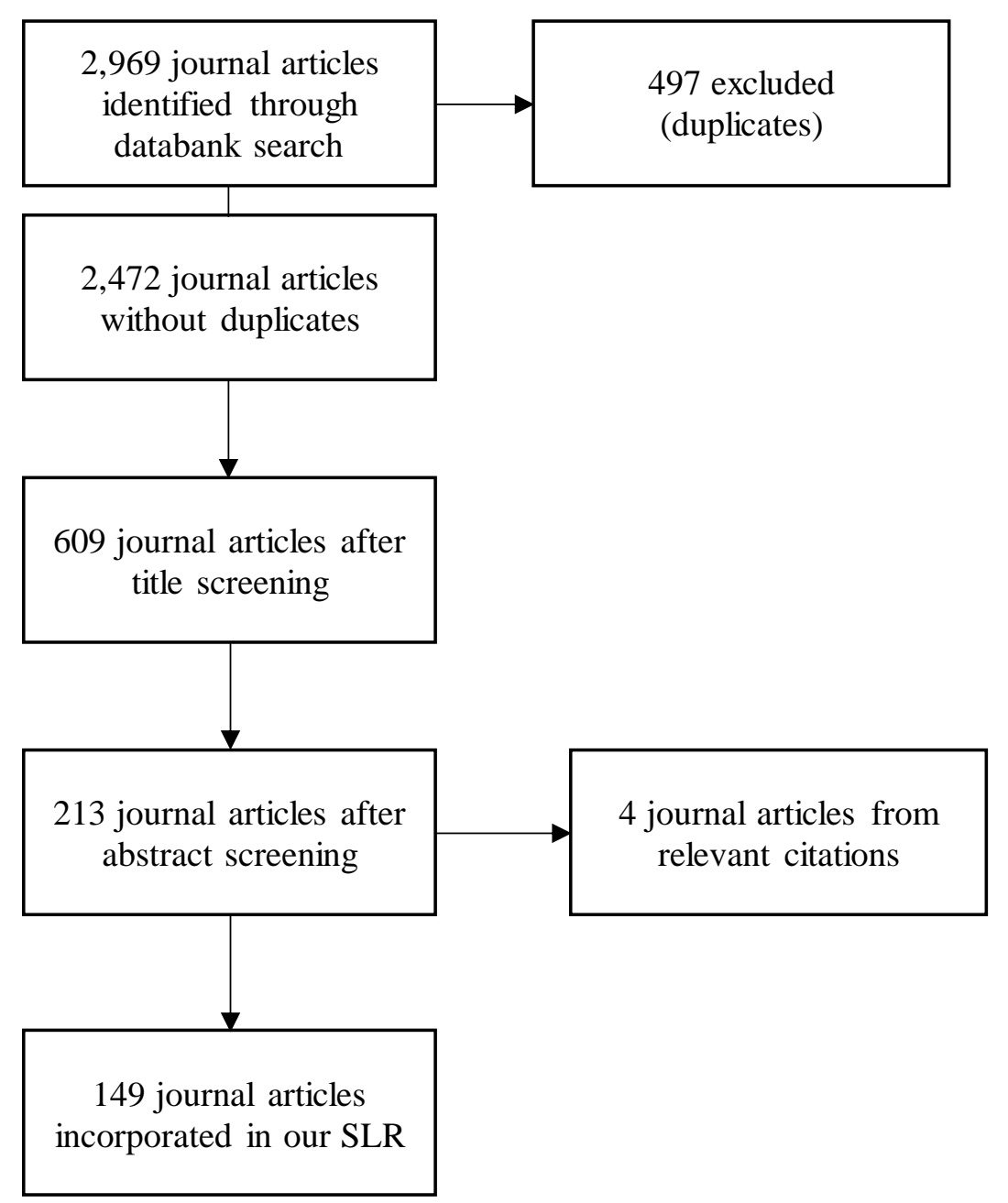

Figure 2. Flowchart of the selection process

\section{Streams of Research in Behavioral Finance}

The eight streams identified in the findings form the root of the structure in the developmental leaps of behavioral finance. First, significant trends were identified concerning behavioral biases. Moreover, the analysis revealed a particular interest in the disposition effect, risk perception, and herding behavior. Following the theoretical framework of behavioral biases, salient approaches to behavioral proxies in different finance models were also covered. Social media and news research emerged as a relatively new area of behavioral finance whose significance has amplified over the past few years. Moreover, weather conditions and calendar effects on asset prices have also been critically examined in current literature. Since many factors impact the investors' mood, further affects influence the sentiment-driven decisionmaking process. Understanding the involved market participants' sentiment appears to be vital to explaining occurred mispricing and predicting future stock market returns. Lastly, our findings revealed that limits to arbitrage might be linked to some financial anomalies. 
Stream 1: New Research in Financial Behavior: Are we even more irrational than we thought?

Barberis and Thaler (2003) have already bestowed consideration on the influence of beliefs on investors' expectations. Today, those beliefs are known under the term behavioral biases. Although the knowledge on this topic was limited in 2003, it has been explored extensively in the period examined here. A behavioral bias, either emotional or cognitive, can be described as a preconceived opinion. Prejudices are known to be a widespread human inclination. While some biases have a logical background, others are emotionally based. However, these irrational aspects of human behavior have an impact on the decision-making process and thus might cause some financial phenomena (Sahi et al., 2013), such as the momentum effect (Galariotis et al., 2014; Hao et al., 2018) or the post-earningsannouncement-drift (Yan \& Zhao, 2018). Other related phenomena include the MAX-effect in reliance on investors' sentiment (Bali et al., 2011), the unusual behavior resulting from daylight or weather-associated sentiment (Gerlach, 2010), and the investors' favoring shares in a preferential company (Aspara \& Tikkanen, 2011).

The SLR revealed that recent research preferentially focuses on one specific bias rather than on the holistic approach of the behavior of market participants. While a variety of cognitive biases, such as conservatism and representativeness (Kariofyllas, Philippas, \& Siriopoulos, 2017; Kräussl \& Mirgorodskaya, 2016), overconfidence, cognitive dissonance, familiarity (Ady, 2018), and anchoring behavior (Anderson \& Zastawniak, 2016; DeLisle, Diavatopoulos, Fodor, \& Krieger, 2017; Lee \& Piqueira, 2019), are based on established concepts, emotional biases usually occur spontaneously and are based on an investor's beliefs or feelings. Table 3 outlines the well-known biases and the related literature to provide a better overview of the different biases.

Table 3. Frequently addressed behavioral and psychological biases

\begin{tabular}{|c|c|}
\hline Type of Bias & Literature \\
\hline Behavioral Bias & $\begin{array}{l}\text { Air pollution, behavioral bias, and the disposition effect in China (Li Jennifer, Massa Massimo, } \\
\text { Zhang Hong, Zhang Jian, 2019) } \\
\text { Behavioral biases in the corporate bond market (Wei Jason, 2018) } \\
\text { Misvaluation and Behavioral Bias in Financial Markets (Gokhale Jayendra, Tremblay Carol } \\
\text { Horton, Tremblay Victor J., 2015) } \\
\text { ABCs of Trading: Bahavioral Biases affect Stock Turnover and Value (Itzkowitz Jennifer, } \\
\text { Itzkowitz Jesse, Rothbort Scott, 2016) } \\
\text { An Exploratory Inquiry into the Psychological Biases in Financial Investment Behavior (Sahi } \\
\text { Shalini Kalra, Arora Ashok Pratap, Dhameja Nand, 2013) } \\
\text { Behavioral biases of mutual fund investors (Bailey Warren, Kumar Alok, Ng David, 2011) } \\
\text { Do Behavioral Biases Adversely Affect the Macro-economy (Korniotis George M. Kumar } \\
\text { Alok, 2011) }\end{array}$ \\
\hline Cognitive Bias & $\begin{array}{l}\text { The Cognitive and Psychological Bias in Investment Decision-Making Behavior. Evidencfe } \\
\text { From Indonesian Investor's Behavior (Ady Sri Utami, 2018) } \\
\text { Cognitive Biases in investor's behavior under stress: Evidence from the London Stock } \\
\text { Exchange (Kariofyllas Spyridon, Philippas Dionisis, Siriopoulos Costas, 2017) } \\
\text { Overcoming Cognitive Biases: A Heuristic for Making Value Investing Decisions (Otuteye } \\
\text { Eben, Siddiquee Mohammad, 2015) }\end{array}$ \\
\hline Underdog Bias & $\begin{array}{l}\text { Potential Underdog Bias, Overconfidence and Risk Propensity in Investor Decision-Making } \\
\text { Behavior (Combrink Sean, Lew Charlene, 2019) }\end{array}$ \\
\hline Anchoring Bias & Glamour, value and anchoring on changing P/E (Anderson Keith, Zastawniak Tomasz, 2016) \\
\hline Confirmation Bias & $\begin{array}{l}\text { How value-glamour investors use financial information: UK evidence of investor's } \\
\text { confirmation bias (Duong Chau, Pescetto Gioia, Santamaria Daniel, 2012) }\end{array}$ \\
\hline Foreign Bias & $\begin{array}{l}\text { A cultural explanation of the foreign bias in international asset allocation (Beugelsdijk Sjoerd, } \\
\text { Frijns Bart, 2010) }\end{array}$ \\
\hline Name-based Bias & $\begin{array}{l}\text { Name-Based Behavioral Biases: Are Expert Investors Immune? (Itzkowitz Jennifer, Itzkowitz } \\
\text { Jesse, 2017) }\end{array}$ \\
\hline Diversification Bias & $\begin{array}{l}\text { Diversification Bias and the Law of One Price: An Experiment on Index Mutual Funds (Mauck } \\
\text { Nathan, Salzsieder Leigh, 2017) }\end{array}$ \\
\hline Negativity Bias & $\begin{array}{l}\text { The powerof bad: The negativity bias in Australian consumer sentiment announcments on stock } \\
\text { returns (Akhtar Shumi, Faff Robert, Oliver Barry, Subrahmanyam Avanidhar, 2010) }\end{array}$ \\
\hline
\end{tabular}


Due to the increasing number of anomalies in the financial market, which traditional asset pricing models cannot explain, attention has been brought to less mathematical approaches. Recent research, therefore, focuses on behavioral biases, which conclusively led to new insights within behavioral finance. Neurofinance research has been groundbreaking as it combines psychology, neuroscience, and finance theory to explain financial decision-making (Cheng, 2014; Taffler, 2017). According to the findings of this review, emotional finance, with particular emphasis on group psychodynamic processes and the human mind as a subcategory of psychoanalysis, plays a significant role in understanding financial decision-making (Taffler, 2017).

In the area of cognitive biases, overconfidence is often discussed either in its own right (Grinblatt \& Keloharju, 2009; Meier \& De Mello, 2019; Merkle, 2017) or in connection to its influence on the market (Adebambo \& Yan, 2016). In financial literature, overconfidence is used as a broad term; however, research suggests that there are at least three subcategories of overconfidence, namely, overestimation, overplacement, and overprecision. It was further found that overplacement and overprecision are closely related to higher risk-taking behavior (Merkle, 2017). Research in this field revealed significant evidence that overconfidence leads to increased trading activity (Deaves, Lüders, \& Luo, 2009). Huang, Heian, and Zhang (2011) provide additional evidence supporting this claim in their study on the impact of overconfidence on excessive trading activity. A difference has been found between individual and institutional traders, where individual investors trade more aggressively with a preference for riskier securities (Chuang \& Susmel, 2011). Overconfidence is also reflected in the difference in momentum profits between the highest (higher momentum profits) and lowest (lower momentum profits) overconfident investor (Adebambo \& Yan, 2016). Furthermore, sentiment as a driver or explanation for momentum effects are addressed in some of the published work in the field (Adebambo \& Yan, 2016; Kim \& Suh, 2018; Uhl, 2017).

In summary, in the early days of behavioral finance, emotional and cognitive biases were referred to as beliefs. It was known that behavioral biases have an impact on investors' expectations and influence financial decision-making. However, little was known about the direct effects of different biases on the decision-making process and which economic phenomena may occur as a result. Over the past ten years, overconfidence has emerged as one of the most significant biases. Merkle (2017) investigated investors' overconfidence and suggested the three-partite subdivision of the term into overestimation, overplacement, and overprecision, ensuring a more detailed analysis of different aspects of phenomena that used to be placed under a single umbrella term. A further significant trend in behavioral finance has emerged. Since psychology became an essential cornerstone in behavioral finance, research has combined insights from neuroscience, psychology, and finance theory under the term Neurofinance. The first results offered invaluable insights into the financial decision-making process, which could not be explained by mathematical finance models (Cheng, 2014; Taffler, 2017). Proceeding from Neurofinance, Taffler (2017) further fuels discussion by urging to complement finance theory with insights from group psychodynamic processes and the human mind, both of which stem from psychoanalysis.

Behavioral bias is used as an umbrella term to refer to the occurrences emerging from human behavior. From this review, three salient behavioral finance issues emerged, namely the disposition effect, investors' risk perception, and herding behavior, which show potential to provide future research with the developmental leaps in those specific subcategories.

\section{Stream 2: Critically Revisiting the Disposition Effect}

One particularly salient finding concerns the disposition effect. Recent literature has not only revisited this effect but also critically questioned its relevance. Thus far, a range of cognitive biases was mentioned; Next to overconfidence, the disposition effect seems to have a significant place in literature, since it has been canvassed a lot over the past three decades (Ferris, Haugen, \& Makhija, 1988; Odean, 1998; Shefrin \& Statman, 1985). Researchers still scrutinize this type of behavior. Hens and Vlcek (2011), for instance, were able to explain ex-post disposition behavior through prospect theory, while ex-ante disposition behavior could not as yet be explicated. Additionally, Braga and Fávero (2017) also argued that it was not possible to fully explain the disposition effect by applying prospect theory.

Further literature indicates that gender has an impact on dispositional behavior. The available evidence seems to suggest that females are usually more risk-averse or, in other words, that males tend to adopt more distinct risk-taking behavior (Cheng et al., 2013; Durand et al., 2019; Meziani \& Noma, 2018). On these grounds, it is argued that the disposition effect is more obvious among females than their male counterparts. Evidence was provided that no loss aversion benefits the circumstance of the disposition effect (Hens \& Vlcek, 2011). In addition, Cheng et al. (2013) suggest that the age or maturity of traders likewise intensifies the disposition effect. Others provided evidence that contrarian investors are more vulnerable to the disposition effect than momentum traders (Kubińska et al., 2012). Cecchini et al. (2019) focused their research on different personality traits in an attempt to explain the disposition 
effect. Their aim was to help investment firms improve their recruiting strategy to create leveraging by examining different personality traits of applicants. Nonetheless, further research especially concerning limitations regarding the observed time horizon and the number of experienced investors in their sample is necessary. Other research focuses on the disposition effect from the perspective of short-sellers. Surprisingly, a short sellers' ability to exploit an arbitrage opportunity is troubled by behavioral biases, which are caused by other market participants' disposition effects (von Beschwitz \& Massa, 2015).

Chang, Solomon, and Westerfield (2016) investigated the connection between cognitive dissonance and the disposition effect. The results of this study affirmed previous knowledge about the disposition effect. However, they observed differences between nondelegated assets like individual stocks and delegated assets like mutual funds. The disposition effect only applies to nondelegated assets, while delegated assets underly a reverse-disposition effect. Besides, cognitive dissonance intensifies both the disposition effect and the reverse-disposition effect.

In comparison to the disposition effect, Hartzmark (2015) introduced a critical theory within which extreme winning and extreme losing positions are sold. The rank effect, as he terms it, applies to both individual investors and mutual fund managers. In conclusion, current research focuses on explaining the disposition effect with particular emphasis on the influence of gender. Moreover, researchers distinguish between delegated and nondelegated assets where different repercussions of the disposition effect have been perceived. Other research suggests different theoretical approaches drawing on the proposed link between cognitive dissonance and disposition effect or the rank effect.

In summary, in terms of demographic factors, gender seems to significantly impact the occurrence and strength of the disposition effect (Cheng et al., 2013; Durand et al., 2019; Meziani \& Noma, 2018). Moreover, maturity (Cheng et al., 2013) and personality traits may be linked to the disposition effect. This insight, in particular, may assist investment firms to restructure their recruiting needs and optimally balance their employees (Cecchini et al., 2019). Stemming from the disposition effect, other researchers shifted their view on similar effects, such as the rank effect (Hartzmark, 2015), to investigate the link between the disposition and the rank effect.

\section{Stream 3: What drives risk perception?}

When we talk about investors, we usually do not distinguish between them according to their gender. Behavioral finance, however, considers gender differences since the decision-making among women and men differs slightly. As a result, the perceived outcome may differ depending on the investors' gender. Thus far, it has been explained that there are significant differences in the risk-taking behavior of women and men. The literature strongly suggests that females are, on average, more risk-averse than their male counterparts (Cheng et al., 2013; Durand et al., 2019; Meziani \& Noma, 2018). Besides gender-based differences, literature broadly focuses on risk perception and trading behavior, such as the incorporation of heterogeneity and cognitive biases in risk perception to improve current assetpricing models (Wang, Keller, \& Siegrist, 2011). Neurofinance also finds explanatory potential in the exploration of the risk-return relationship (Bekiros, Jlassi, Naoui, \& Uddin, 2018). Furthermore, new insights show that the investors' cognitive ability directly influences risk preferences. Namely, higher cognitive ability tends to coincide with the expected utility maximization (Ackert, Deaves, Miele, \& Nguyen, 2019). Others focus on the effect of individual investors' risk perception on market prices. Huber, Palan, and Zeisberger (2019) tested links between risk perception and asset prices while focusing on the probability of suffering a loss. Consequently, investment decisions are linked to the probability of suffering a loss relative to the nominal value of an asset, which drives the risk perception of investors. Thus, prices are directly affected in that those assets which are on average perceived as riskier are traded at a lower price. Further evidence of this is provided by Elliot, Rennekamp, and White (2017) on an undocumented behavioral effect that directly influences individual investors' risk perception. Their findings suggest that investors with a directional goal neglect their risk perception when assessing value. Additionally, research also shows that risk perception exhibits a link to herding behavior. More risk-averse individuals are more likely to herd than their more risk-tolerant counterparts (Christoffersen \& Stæhr, 2019).

\section{Stream 4: Has herding behavior changed in the past years?}

Herding behavior can be observed in financial markets and in any other areas where a significant number of people come together. Moreover, herding has always been a phenomenon attracting much research. The reason for this is that aggregated behavior of a group of investors cannot be ignored. The preceding section already addressed risk perception, which has been defined as an intuitive reaction potentially leading to herding behavior given lower risk tolerance (Christoffersen \& Stæhr, 2019). Herding has always prevalent in financial markets. Lakonishok, Shleifer, 
and Vishny (1992), for instance, have looked into herding and positive-feedback trading. The present findings show that herding continues to be seen as relevant in current literature (Muñoz Torrecillas, Yalamova, \& McKelvey, 2016). First, Andersson, Hedesström, and Gärling (2014) have addressed the distinction between rational and irrational herding. While some argue that herding behavior might stabilize the market (Drehmann, Oechssler, \& Roider, 2005), others find that social influence and inaccurate perceptions of the herd should be labeled as irrational herding behavior (Andersson et al., 2014). Besides the common information-based herding (Zhou \& Lai, 2009), another potential reason for herding s reputational herding. The first laboratory experiment concerning reputational herding based on Dasgupta, Prat, and Verardo (2011) was conducted by Roider and Voskort (2016), where it was shown that factors such as career concerns might play a role in herding behavior. Dasgupta et al. (2011) conclude that money managers tend to imitate past trades and tend to herd to avoid reputational loss. Their model further showed a link between herding behavior, trading volume, and the time series of stock returns. Second, herding behavior was found to be more prevalent in futures markets than in equity markets. This may be so as futures markets, where the information is essentially publicly available, reduce herding, while contrarian trading, where access to information is limited, enhances herding (Boyd, Büyükşahin, Haigh, \& Harris, 2016). Third, herding has been investigated from a country perspective. Already in 2000, herding behavior in different international markets was observed. Findings showed no evidence of herding in the U.S. or Hong Kong, partial herding in Japan and South Korea, and Taiwan. However, Bohl, Branger, and Trede (2017) provided new insights and disproved that earlier research was biased against finding evidence in favor of herding. Thus, their findings confirm the significance of herding behavior in international markets and put forward that economic reasons for herding are reputational and career concerns, informational cascades, and the compensation factor. Besides, Chen (2019) suggests that country herding intensifies or mitigates in correlation with the positive or negative sentiment in the market. Gębka and Wohar (2013) investigated the herding differences across different sectors and found that herding intensity is higher in the oil and gas sector, consumer services, and essential materials. Herding was significantly less prominent in industrial goods, properties and construction, information technology, and utilities (Gębka \& Wohar, 2013; Zhou \& Lai, 2009). Those results foster debate about sector-specific herding traits since these findings are in contrast to the findings of Hwang and Salmon (2004) and Kremer and Nautz (2013), who argue that herding may be most common in sectors with inferior information quality and quantity.

In summary, three developmental leaps dominate research on herding behavior. Herding behavior does not always have negative consequences since distinction can be made between irrational and rational herding (Andersson et al., 2014). Moreover, research into herding behavior might be more revealing in futures markets than equity markets (Boyd et al., 2016). Further fragmentation of herding behavior per country and sector might help understand herding intentions.

An overview was provided of different emotional and cognitive biases found in financial markets. Some biases, such as the anchoring or overconfidence, have been accounted for since the dawn of behavioral finance (Barberis \& Thaler, 2003), while others, especially emotional biases, required insights from other fields of research, such as psychology and neuroscience, to assist in understanding human behavior (Taffler, 2017). With this in mind, let us turn to the next salient stream of research. New insights have led researchers to develop new theoretical models, which might be able to illustrate not only the financial factors but also investors' irrational behavior.

\section{Stream 5: New theoretically founded models and approaches: Are they really better?}

Over the last 55 years, much research has been conducted by pioneers who tried to understand and predict market behavior (Black, Jensen, \& Myron, 1972; Fama, 1970; Fama \& French, 1992; Samuelson, 1965; Shleifer \& Vishny, 1997). Many have set out to investigate topics within behavioral finance, which, as a field, provides new ways of predicting and modeling future asset prices and stock return. As mentioned beforehand, both types of biases, cognitive and emotional, constitute a deviation from the rational behavior of economic agents as the efficient-market hypothesis $(\mathrm{EMH})$ and other rational models suggest. Although the adaptive market hypothesis, as proposed by Farmer and Lo (1999), suggested a more realistic approach, researchers have focused on developing new approaches. The question that is often posed within the field is: What drives investment decisions? Individual investors are influenced by emotions and sentiments contributing to the increased volatility in financial markets (Cheng, 2014). Irrationality is highly associated with investors' decision-making, yet many financial theories are based on the assumed agent's rationality (Cohen \& Kudryavtsev, 2012). The findings of this analysis revealed different approaches to reasonably predicting financial decision-making. Brown, Farrell, and Weisbenner (2016) focus on different decision-making approaches such as procrastination, while Cheng (2014) developed a decision utility model based on recent findings in Neurofinance regarding prospect-based foundation including decision utility and anticipated discrete emotions. A 
groundbreaking test in the field included measuring brain activity during the experimental financial decision process. The neural data-enabled testing realization utility to explain the participants' behavior. Researchers suggest using brain imaging techniques to assess how neural measures can impact trading behavior (Frydman, Barberis, Camerer, Bossaerts, \& Rangel, 2014). Furthermore, Vieito, da Rocha, and Rocha (2015) used electroencephalogram technologies to map the brain during financial decisions on holding, selling and buying. Additionally, a new turn was taken by including character traits as variables in the context of decision-making. Oehler, Wendt, Wedlich, and Horn (2017) found that extraversion and neuroticism influence financial decision-making. Extraverted investors tend to pay more for risky assets, while neurotic investors tend to buy less risky assets. Lam, Liu, and Wong (2012) developed a model with the idiosyncrasy that an investor can represent both conservative and representative heuristics at the same time enhanced by a pseudo-Bayesian approach for explaining some ubiquitous anomalies in the financial market.

Another approach in current literature is the adjustment of mathematical models, such as the Black-Scholes model, for certain biases, for instance, anchoring (Siddiqi, 2019), or the development of methods that prevent the influence of biased parameters to enable the investor to avoid cognitive bias problems (Otuteye \& Siddiquee, 2015). Besides, some researchers argue that there is a lack of predictive methods for identifying and estimating the degree of valuation bias in financial markets for detecting misvaluation caused by behavioral biases (Gokhale et al., 2015). In contrast to the approaches mentioned above, Cronqvist and Siegel (2014) fostered debate on the influence of genetics on individual trading behavior. They showed evidence that genetic endowments may correlate with individual investment behavior. According to them, genes may be related to familiarity, overconfidence, sensation-seeking, and intelligence. McCannon and Peterson (2015) found that a prior financial education amplifies wealth-generating activities regarding decision making. The authors suggest that those investors with prior financial education are more likely to exhibit prosocial rather than selfish behavior. In contrast, Bodnaruk and Simonov (2015) found no evidence of investors with higher financial expertise outperforming those with less financial expertise. Their findings further show there has been no significant superior risk diversification or sensitivity to exhibit behavioral biases.

In the beginning, finance models were grounded on the assumption of efficient markets where almost all investors act as rational agents, while the impact of the few irrational investors is quickly reversed by arbitrageurs (Fama, 1970; Shleifer \& Vishny, 1997). Today, research shows that new models take irrational behavior into account, leading to more accurate descriptions. Besides the decision utility model enriched by insights from Neurofinance (Cheng, 2014), brain imaging techniques have been used to assess neural measures, which might help to demonstrate emotionality in decision-making (Frydman et al., 2014). As most of these models and approaches are relatively new to the field, others have adapted well-established models, such as the Black-Scholes model, to account for certain biases such as anchoring (Siddiqi, 2019). Interestingly, compared to earlier research, some approaches consider the influence of genetics and education, which deserve attention in their own right (Cronqvist \& Siegel, 2014; McCannon \& Peterson, 2015). In what follows, let us explore whether and calendar effects as well as the influence of social media, which are also relatively new to the field of behavioral finance.

\section{Stream 6: Sunshine, Twitter, and Co.: Should we really consider it?}

Technology has become increasingly more important over the past few years. This development leads to a new aspect of behavioral finance as news is now constantly available and the influence and importance of social media have grown exponentially since Facebook and Twitter were established. Nonetheless, media has always been an influential factor in financial markets. The importance of media and news is constantly increasing due to the fast development of news sources (Peress, 2014). Therefore, current literature provides a comprehensive outlook on approaches predicting the influence of media and news on future stock market returns and asset pricing. Ammann, Frey, and Verhofen (2014) formulate recommendations based on seven or more clusters of news sources necessary to predict future stock returns. Conclusively, news can be used as a predictor for future stock market developments. The impact of social media on financial markets has recently been the topic of some concern. Social media bots, for example, might lead to instability through fake information dispersion. Nonetheless, social media might help to yield transparency in information spread (Fan et al., 2019). Literacy and attentiveness might help avoid irrational trading behavior. Notably, Twitter has been recognized as a relevant source among social media news outlets on topics regarding economic development, political volatility, and enterprise information, which conclusively might lead to aggregated trading behavior (Reed, 2016). This influence of mass media on the formation of investors' expectations has led to different approaches. Carretta, Farina, Martelli, Fiordelisi, and Schwizer (2011) find that news's different tones and content trigger investors' behavior. The impact of ownership-related news for profitable firms is predominantly negative, often leading to a disposition of stocks. Others argue that investors might suffer from 
information overload. Conclusively, information processing is affected so that investors might respond less strongly to media news (Peress, 2014). Savor (2012) claims that investors might underreact to news about fundamentals and overreact due to other shocks leading to stock price changes. Further, a strong correlation has been found between the ratio of no-information and information-based price shocks and the aggregate implied volatility, which may help forecast momentum returns (Mangee, 2018). Google search trends revealed that in contrast to former literature, extensive Google searches are followed by negative returns. Although it is suggested that Google might be able to predict future stock returns, there is evidence that this effect is somewhat unsteady over time (Bijl, Kringhaug, Molnár, \& Sandvik, 2016; Dimpfl \& Jank, 2016).

Momentum has consistently contradicted the efficient market hypothesis. This anomaly is often explained away using different approaches. In terms of media impact, Huynh and Smith (2017) found that momentum is greater due to news coverage. Consequently, we need to distinguish between different types of news outlets as they have a varying effect on the intensity of investors' underreaction. In contrast, other literature suggests that macroeconomic and earnings news enhance overall efficiency since investors might be more able to interpret earnings surprises and perform a more efficient stock valuation. Chahine, Mansi, and Mazboudi (2015) suggest distinguishing between informative and uninformative media news. Both have different significant effects on pricing and equity carve-outs (ECO). While uninformative news amplifies earnings management on ECO performance, informative news reduces it. Earlier findings have shown that in extreme weather events where newspaper dispersion was interrupted, a strong link between media and trading behavior was recognized. Today, the same can still be observed as media drives trading activity (Engelberg \& Parsons, 2011).

Besides the previously presented findings of how market social media and news persistence affect asset pricing, calendar effects, seasonality, and the weather play a significant role. Current research focuses on four different calendar effects, in particular known as the Monday effect, January effect, Halloween effect, and Turn-of-the-Month effect (Chen \& Daves, 2018; Urquhart \& McGroarty, 2014). Evidence was provided on the bi-directional timevarying behavior of the four calendar anomalies consistent with the adaptive market hypothesis but not the efficient market hypothesis (Urquhart \& McGroarty, 2016).

January effect, in particular, has been well-studied. Investors tend to reevaluate their investment decisions in January and their demand for risky assets for the remaining months of the year. Investors' economic outlook and thus stock market returns from February to December are affected by the January effect. The other January effect (OJE) has been researched as well, and advice was given against the use of the OJE since the information gathered from the tool might not be helpful as January is not unique in its capability to predict stock market returns (Bohl \& Salm, 2009; Marshall \& Visaltanachoti, 2010). Another market efficiency puzzle is the Halloween effect. Although first observed some time ago, it is still present according to more recent sources (Jacobsen \& Visaltanachoti, 2009). This persistent anomaly has been interesting for investors due to the greater risk-adjusted returns available by investing in a Halloween portfolio (Haggard \& Witte, 2010). Similar to the already mentioned anomalies, new year celebrations in different cultures worldwide affect investors' mood and positively influence stock prices through cash infusions and retail trading (Bergsma \& Jiang, 2016). Since most of the holidays are religious holidays, the religious background of the market participants plays a notable role in analyzing the holiday effect because a significant number of foreign investors might influence the prevalent belief system. Conclusively, foreign influence is reflected in the stock market returns of the local market (Bley \& Saad, 2010).

Seasonality has been recently studied in terms of risk and returns. Earlier findings already canvassed the link between beta and returns (Black et al., 1972; Fama \& French, 1992). Keloharju, Linnainmaa, and Nyberg (2016) suggest that return seasonalities cannot be treated as a distinct class of anomalies but rather as an interconnected condition with other return anomalies. According to them, different systematic factors, such as size, dividend-toprice, or industry, influence the occurrence of return seasonalities. Further research in this field revealed that the seasonality phenomenon might be attributed only to developed markets and not emerging ones. This difference might be attributable to various reasons such as regression bias, firm size, risk premium, and calendar effects ( $\mathrm{Li}$, Zhang, \& Zheng, 2018). Moreover, Fiore and Saha (2015) suggest that the risk-return tradeoff retains in non-summer months. Conclusively, portfolios of low-risk stocks in summer outperform other buy and hole strategies as the Sell in May strategy. Heston and Sadka (2010) argue that seasonal strategies outperform nonseasonal strategies based on their seasonal predictability study. Furthermore, a relatively low correlation across countries concerning seasonal strategies has been noticed.

Next to calendar effects and seasonality, the literature also sheds light on how weather influences trading volume and asset pricing (Kim, 2017). Goetzmann et al. (2015) demonstrated that weather-based indicators of mood influence the decision-making of institutional investors. During cloudier days, the study revealed increased perceived overpricing in individual stocks as opposed to sunny days. On the other hand, Schmittmann, Pirschel, Meyer, and 
Hackethal (2015) distinguished retail and institutional investors and focused on weather variables and their influence on retail investors. On sunnier days, the tendency to purchase is higher relative to sales. Furthermore, the demand to purchase riskier securities and sell the less risky ones is higher on good weather days. This claim is corroborated by Bassi, Colacito, and Fulghieri (2013), whose test showed that good weather increases investors' risk perception. Conversely, Pizzutilo and Roncone (2016) have raised doubts as they failed to identify a systematic correlation between weather variables and the stock market. Their conclusion is similar to that of Kaustia and Rantapuska (2016), who also did not find a significant repercussion of weather-induced mood on the trading behavior. Whereas findings showed a weak correlation between weather conditions and trading volume, it was not statistically significant.

In summary, it can be said that the influence of social media and news should not be ignored but instead considered in future research since no holistic approach toward the influence of social media has yet been taken. Calendar effects, such as the Halloween effect or the January effect, influence trading volume and might lead to mispricing (Chen \& Daves, 2018; Urquhart \& McGroarty, 2014). Moreover, risk perception changes were investigated concerning weather conditions (Bassi et al., 2013; Schmittmann et al., 2015). However, the robustness of the findings confirming the hypothesis has been criticized since some studies failed to demonstrate the influence of weather conditions on trading behavior (Kaustia \& Rantapuska, 2016; Pizzutilo \& Roncone, 2016).

\section{Stream 7: How do you feel today? The influence of sentiment on asset prices}

In discussions on behavioral finance, one term simply cannot be ignored. The market sentiment reflects the overall attitude of investors towards the market and securities. This research strand is indebted to De Long, Shleifer, Summers, and Waldmann (1990), Shleifer and Vishny (1997), and others for their discovery of sentiment as a pricing factor that should work in equity markets. Unfortunately, traditional economic theory has largely ignored the significance of sentiment due to its assumed lack of importance or complexity (Shu \& Chang, 2015). The sentiment, which is divorced from rationality, illustrates the entangled nature of the human mind. Therefore, it is not surprising that sentiment has been used as a generic term associated with emotions and mood (Siganos, Vagenas-Nanos, \& Verwijmeren, 2017). Recent literature confirmed that sentiment should be incorporated into theoretical models since the derived information may be more significant, especially the pricing of sentiment risk (Chang, Cheng, \& Fuh, 2013; Du \& Hu, 2017; Hwang, 2011; Keiber \& Samyschew, 2018). Since investors' sentiment has been identified as a significant contributing factor to asset price changes, it has become an increasingly important area in behavioral finance (Chau, Deesomsak, \& Koutmos, 2016; Huang, Jiang, Tu, \& Zhou, 2015; Schmeling, 2009; Sibley, Wang, Xing, \& Zhang, 2016). In the early 2000s, Baker and Wurgler (2006) conducted particularly insightful research into the importance of market sentiment. The present analysis revealed different approaches within the research on investors' sentiment. The general consensus is that negative as well as positive market sentiment affects investment decisions and market prices as a result (Kaplanski \& Levy, 2010).

The available evidence seems to suggest that overvaluation, hence, overpricing, is strongly linked to market sentiment (Berger \& Turtle, 2015; Jacoby \& Liao, 2012; Yang, Goh, \& Chiyachantana, 2016). Berger and Turtle (2015) provide strong evidence that, in the short term, increased sentiment positively affects returns due to overvaluation, which steadily reverses as arbitrageurs even out the effect by trading against behavioral traders and thus correcting prices. It is thus suggested that investor sentiment may act as a contrarian indicator for subsequent returns. These findings are complemented by Yang et al. (2016), who show that overpricing is more dominant when bullish market sentiment prevails. They further suggest that younger, somewhat volatile firms are particularly affected by mispricing due to sentiment-driven overvaluation. This assertion has been confirmed by Chue, Gul, and Mian (2019), whose analysis of stock return synchronicity and sentiment focused on young and volatile low-priced stocks.

Driven by the demand to explain financial market anomalies, many researchers focused on the influence of sentiment. Cheng (2014) and (Taffler, 2017) focused on the interconnectedness of psychology, neuroscience, and finance, which led to the relatively new research stream of neuroscience. Based on their research of investors' sentiment, Shu and Chang (2015) suggest a similar approach to enhance traditional economic models by relying on insights from other fields such as psychology. They provide evidence for the lack of asset-pricing models with incorporated mood and emotional factors. Nonetheless, research focused on the investigation of investors' sentiment and some market anomalies. Fong (2013) reported a strong correlation between sentiment and the MAX effect. In their research, they confirmed the presence of the MAX effect, first discovered by Bali et al. (2011). The initial investigation showed that the MAX effects' occurrence depends on previous high investor sentiment states. Conclusively, high MAX stocks in connection with high sentiment strongly indicate overpriced stocks. A study by Blau (2018) supports the view that asset prices are susceptible to deviation from their fundamental value. Besides, his study found that price clustering is higher during periods of higher investor sentiment states. 
To elaborate on the interconnectedness of these findings, Altanlar, Guo, and Holmes (2018) investigated the link between cognitive dissonance, sentiment, and cultural effects. They suggest distinguishing between Western and East Asian cultures and provide further evidence that both culture and sentiment impact cognitive dissonance. Moreover, other recent studies showed correlations between sentiment and the weather or daytime, which led to different financial decisions (Gerlach, 2010; Gregory-Allen, Jacobsen, \& Marquering, 2010; Kim, 2017). From another perspective, Hilliard, Narayanasamy, and Zhang (2019) examined mutual fund flows and market sentiment. They report that investments in riskier fund categories rise as the market sentiment increases while the demand for safer fund categories rises when sentiment goes down. The high demand for risky assets after a sentiment shock has been confirmed by Liang (2018) and further addressed by Edelen, Marcus, and Tehranian (2018). Further evidence from the mutual fund industry confirms that the highly negative impact of synchronicity only occurs in low sentiment times (Dong \& Wilson, 2018).

Predicting future stock returns is one of the major aims of the research. Sentiment has been a driving force in earlier and contemporary literature where different proxies for measurement became available (Zhang, Swanson, \& Prombutr, 2012). Following pioneers in the field, such as Baker and Wurgler (2006), sentiment indexes remain a significant area of research. Du and $\mathrm{Hu}$ (2017) attempted to show that the influence of sentiment on asset pricing is much weaker when the Fama-French-Carhart factors are present. Their findings further suggest that Fama-French factors might be able to capture sources of mispricing due to market-wide sentiment, which again confirms the hypothesis that asset-pricing models that include sentiment as a pricing factor might be more informative. In terms of sentiment indexes, several developmental leaps can be observed. Zhang et al. (2012) introduced four new methodological improvements and selected text classifiers to augment the predictive ability of sentiment indexes focusing on retail investors. Based on the work of Baker and Wurgler (2006), Huang et al. (2015) proposed a new measure of investors' sentiment. They suggest that return predictability is somewhat dependent on investors' beliefs about future cash flow than on the underlying discount rate. The new measure also serves as a better forecasting model for stock returns since it is formed on industry, size, value, and momentum. Furthermore, Sibley et al. (2016) divided the well-known sentiment index into two components, where the first is related to fundamental variables and the second unrelated to them. They suggest that the prediction of stock returns is significantly more dependent on risk/business cycle components. One recent study shows that sentiment metrics account for institutional rather than individual investors' demand shocks. It is further suggested that the link between sentiment metrics, institutional, and individual investors should be investigated in future research since it is much more nuanced than initially assumed (DeVault, Sias, \& Starks, 2019).

In summary, earlier studies rarely paid attention to sentiment as a pricing factor. Today, however, we know of the strong link between mispricing, especially overvaluation, and sentiment. This research development helps explain overpricing, especially that of younger and volatile firms (Berger \& Turtle, 2015; Jacoby \& Liao, 2012; Yang \& Wu, 2011). Furthermore, the ubiquitous development in Neurofinance pervades many topics in behavioral finance. Shu and Chang (2015) likewise suggest that finance theory and psychology should collaborate to enhance asset-pricing models to better understand sentiment. Besides Neurofinance, Altanlar et al. (2018) investigated sentiment and its different effects in Western and East Asian cultures. Their analysis showed that cognitive dissonance might be impacted by sentiment. The foundational observations of sentiment indexes introduced by Baker and Wurgler (2006) have been critically revisited and partially adapted to provide more precise return predictability (DeVault et al., 2019; Huang et al., 2015; Sibley et al., 2016; Zhang et al., 2012).

\section{Stream 8: Looking for an explanation: New anomalies as a playground for researchers}

Limits to arbitrage have always been an important topic within behavioral finance, exemplified by the influential papers by Shleifer and Vishny (1997) and Barberis and Thaler (2003). The deviation of asset prices from their fundamental value is a widely discussed topic in literature. New findings suggest that investors' demand shock may lead to mispricing (Gromb \& Vayanos, 2010). Further, price efficiency is heavily dependent on the intervention of arbitrageurs to correct occurred mispricing. Even small arbitrageurs can make a difference in partially retrieving fundamental values (Ljungqvist \& Qian, 2016), which confirms former findings. Over the past ten years, different approaches have seized on limits to arbitrage. In exploring the Shleifer-Vishny model of limits to arbitrage, Arnold (2009) looked beyond its parameter restrictions. He discovered an equilibrium in which the asset price returns to fundamental value despite worsening noise trader sentiment. Hombert and Thesmar (2014) conducted their research on a delegated fund management model in equilibrium. The outcome suggests that while limits to arbitrage are contemporary, a more robust capital structure may lead to a mitigating effect, and it further drives capital structure strength and the momentum of asset returns. Another approach shows that a modified MAX measure, where the 
problem of price regulation is eliminated, could be used as an alternative proxy for arbitrage risk (Hung \& Yang, 2018).

Besides the diachronic development of different approaches, limits to arbitrage have been associated with different financial anomalies (see Table 3). With regard to the asset growth anomaly, a strong correlation has been found between proxies for limits to arbitrage and proxies for investment frictions (Lam \& Wei, 2011). Furthermore, the arbitrage for both asset growth and accrual growth anomaly is difficult, and it poses substantially higher risks, which indicates that both anomalies exist due to high barriers to arbitrage (Li \& Sullivan, 2018). The turnover anomaly was investigated by Chou et al. (2012), who concluded that the turnover effect might be an indicator for future returns. The theory assumes that the turnover premium is greater in idiosyncratic volatility, transaction costs higher, and the institutional ownership and investors' sophistication lower. Thus, a link has been found between the mispricing on arbitrage risk and the turnover effect. Recent research further sheds light on another economic phenomenon, namely, the low-volatility anomaly. The underperformance of high-beta and high-volatility on the contrary to low-beta and low-volatility stocks led researchers to explain that institutional investors' targets to beat fixed benchmarks diminished arbitrage activity. In other words, irrational investors take the opportunity to overpay, while investment managers avoid such mispricing due to the missing incentive (Baker, Bradley, \& Wurgler, 2018; Li, Sullivan, \& Garcia-Feijóo, 2018). Lastly, evidence has shown that overvaluation anomalies can be explained by more significant limits to arbitrage, such as idiosyncratic risk but not by the noise trader momentum risk. However, no explanation for undervaluation anomalies connected with limits to arbitrage has been provided (Brav, Heaton, \& $\mathrm{Li}, 2010$ ). This section addressed the important topic of limits to arbitrage. Earlier research is still validated, while some new findings accentuate the implications of limits to arbitrage (Arnold, 2009; Gromb \& Vayanos, 2010; Ljungqvist \& Qian, 2016). During the analysis, one area of research protruded and was addressed in more depth. Five different market anomalies have been associated with limits to arbitrage, all of which constitute a relatively new research stream (Baker et al., 2018; Brav et al., 2010; Chou et al., 2013; Lam \& Wei, 2011; Li \& Sullivan, 2018; Li, Sullivan, et al., 2018).

Table 4. Types of anomalies associated with limits to arbitrage

\begin{tabular}{ll}
\hline Type of Anomaly & Literature \\
\hline \multirow{2}{*}{ Asset Growth Anomaly } & $\begin{array}{l}\text { Limits-to-arbitrage, investment frictions and the asset growth } \\
\text { anomaly (Lam F.Y. Eric C., K.C. John, 2011) }\end{array}$ \\
& $\begin{array}{l}\text { The Limits to Arbitrage Revisited: The Accrual and Asset and } \\
\text { Asset Growth Anomalies (Li Xi, Sullivan Rodney N., 2018) }\end{array}$ \\
Accrual Growth Anomaly & $\begin{array}{l}\text { The Limits to Arbitrage Revisited: The Accrual and Asset and } \\
\text { Asset Growth Anomalies (Li Xi, Sullivan Rodney N., 2018) }\end{array}$ \\
Turnover Anomaly & $\begin{array}{l}\text { Arbitrage risk and the turnover anomaly (Chou Pin-Huang, } \\
\text { Huang Tsung-Yu, Yang, Hung-Jeh, 2013) }\end{array}$ \\
& $\begin{array}{l}\text { Benchmarks as Limits to Arbitrage: Understanding the Low- } \\
\text { Volatility Anomaly (Malcom Baker, Bradley Brendan, }\end{array}$ \\
Wurgler Jeffrey, 2018) \\
The Limits to Arbitrage and the Low-Volatility Anomaly (Li \\
Xi, Sullivan Rodney N., Garcia-Feijóo, Luis, 2018) \\
The Limits of the Limits to Arbitrage (Brav Alon, Heaton J. \\
B., Li Si, 2010)
\end{tabular}

\section{Conclusion}

This systematic literature review investigated the developments in the literature on behavioral finance. Driven by the demand to understand recent developments, the objective was to identify future research agendas by providing a holistic picture of the current behavioral finance environment. While the foundation was laid down by Barberis and Thaler (2003), the developmental leaps in research from 2009 to 2019 were explored. To accomplish this goal, 36 highly rated finance journals were evaluated based on our pre-defined keywords and their corresponding search terms. Whereas the initial search resulted in 2,472 journal articles, following title and abstract screening, those articles were excluded that did not cohere with the inclusion criteria nor provide answers to the questions. The search thus resulted in selecting 149 articles for the systematic literature review. To provide a rounded framework of the research 
development, the findings were clustered into emerged research streams. Still, the dominant research stream discusses behavioral biases and their implications on financial markets. The most prominent development concerns the relatively new field of Neurofinance, which combines knowledge from psychology, neuroscience, and finance theory to understand human decision-making (Cheng, 2014; Taffler, 2017). Time and again, the analysis showed that neuroscience has become part of the extended investigations on the financial decision-making process (Shu \& Chang, 2015) as it further enhanced asset-pricing models to provide better predictability (Huang et al., 2015). Moreover, new theoretically founded models were introduced that lays out the problem of behavioral biases in classical asset-pricing models (Cohen \& Kudryavtsev, 2012). The most salient findings hereby are the development of a decision utility model (Cheng, 2014), the usage of brain imaging techniques to assess neural measures (Frydman et al., 2014), and the additional use of electroencephalogram technologies to map the brain during financial decision-making (Vieito et al., 2015). From yet another perspective, Cronqvist and Siegel (2014) and McCannon and Peterson (2015) foster debate on the influence of genetics and education on financial decision-making.

Besides the established behavioral finance terms, which are regularly investigated and adapted, a relatively new stream of research deals with the market biases caused by social media, weather, and calendar effects. While the new development in technology leads to more transparency, media and news might also have a negative impact due to the potentially rapid spread of fake information (Reed, 2016). Furthermore, the omnipresent increase of the interconnectedness between the media and the financial market leads researchers to further investigate possible development possibilities and related threats (Fan et al., 2019; Peress, 2014). Since evidence has shown that sentiment may play a key role in overvaluation anomalies and mispricing (Berger \& Turtle, 2015; Jacoby \& Liao, 2012; Yang $\& \mathrm{Wu}, 2011$ ), recent research has been driven by the demand to predict future stock market returns and to understand unresolved financial phenomena. Besides using other research domains such as Neuroscience and Psychology to understand the market sentiment (Shu \& Chang, 2015), evidence has uncovered potential cultural differences in sentiment between Western and East Asian cultures. Thereafter recent literature on sentiment indexes was further investigated. Results showed that sentiment indexes still bear little predictability potential. Nonetheless, based on the foundation laid by Baker and Wurgler (2006), many researchers investigated and adapted sentiment indexes to enhance predictability potential (Du \& Hu, 2017; Huang et al., 2015; Sibley et al., 2016; Zhang et al., 2012). The last salient stream of research deals with the well-known topic of limits to arbitrage. Surprisingly, a relatively new discovery was the connection between limits to arbitrage and some financial market anomalies. The formation of some anomalies, such as the asset growth anomaly or the low-volatility anomaly, might be explained, research suggests, by looking at the theory of limits to arbitrage (Baker et al., 2018; Brav et al., 2010; Chou et al., 2013; Lam \& Wei, 2011; Li \& Sullivan, 2018; Li, Sullivan, et al., 2018).

For future research, a great challenge will be the holistic understanding of neural data in terms of financial decision-making (Frydman et al., 2014). Since biases affect rational decision-making, Neurofinance helps to identify some of the biases identified in behavioral finance. Nonetheless, the research into the interplay between the different research domains of psychology, neuroscience, and finance theory is still in its inception (Taffler, 2017). Emphasis should be placed on further investigation of the human mind connected with brain imaging techniques to compile a data set for emotional decision-making and its connection to financial phenomena (Cheng, 2014; Shu \& Chang, 2015). Besides the influence of genetics on financial decision-making, further research might also focus on the influence of former experiences influencing investors' financial decisions (Cronqvist \& Siegel, 2014). As a foundation, the correlation with the prominent literature on narrative economics published by Shiller (2019) might be helpful to further investigate its influence on human decision-making.

Once more, the influence of social media on the financial market should be highlighted. Technology is rapidly enhancing, and increasingly people are gathering information in real-time via online platforms. This development brings with it both threats and opportunities for future research seeing that established models might need to be augmented by social media factors (Fan et al., 2019). A further stream of research linked to media and news might investigate the influence of layout, tone, and content of information. It hereby is important not only to focus on corporate announcements (Carretta et al., 2011) but also on statements made by prominent entrepreneurs, businesspeople, and economists. The information shared on microblogging sites such as Twitter requires more detailed investigation since their impact on investors' decisions has not been measured as of yet. 


\section{References}

Ackert, L. F., Deaves, R., Miele, J., \& Nguyen, Q. (2019). Are Time Preference and Risk Preference Associated with Cognitive Intelligence and Emotional Intelligence? Journal of Behavioral Finance, 21(2), 136-156. doi:10.1080/15427560.2019.1663850

Adebambo, B. N., \& Yan, X. S. (2016). Momentum, Reversals, and Fund Manager Overconfidence. Financial Management, 31.

Ady, S. U. (2018). The Cognitive and Psychological Bias in Investment Decision-Making Behavior: (Evidence From Indonesian Investor's Behavior). Journal of Economics and Behavioral Studies, 10(1). doi:10.22610/jobs.v10i1.2092

Aguinis, H., Ramani, R. S., \& Alabduljader, N. (2018). What You See Is What You Get? Enhancing Methodological Transparency in Management Research. Academy of Management Annals, 12(1), 83-110. doi:10.5465/annals.2016.0011

Altanlar, A., Guo, J., \& Holmes, P. (2018). Do culture, sentiment, and cognitive dissonance explain the 'above suspicion' anomalies? European Financial Management, 25(5), 1168-1195. doi:10.1111/eufm.12203

Ammann, M., Frey, R., \& Verhofen, M. (2014). Do Newspaper Articles Predict Aggregate Stock Returns? Journal of Behavioral Finance, 15(3), 195-213. doi:10.1080/15427560.2014.941061

Anderson, K., \& Zastawniak, T. (2016). Glamour, value, and anchoring on the changing P/E. The European Journal of Finance, 23(5), 375-406. doi:10.1080/1351847x.2015.1113192

Andersson, M., Hedesström, M., \& Gärling, T. (2014). A Social-Psychological Perspective on Herding in Stock Markets. Journal of Behavioral Finance, 15(3), 226-234. doi:10.1080/15427560.2014.941062

Arnold, L. G. (2009). Anything is Possible: On the Existence and Uniqueness of Equilibria in the Shleifer-Vishny Model of Limits of Arbitrage. Review of Finance, 13(3), 521-553. doi:10.1093/rof/rfn016

Aspara, J., \& Tikkanen, H. (2011). Individuals' Affect-Based Motivations to Invest in Stocks: Beyond Expected Financial Returns and Risks. Journal of Behavioral Finance, 12(2), 78-89. doi:10.1080/15427560.2011.575970

Baker, M., Bradley, B., \& Wurgler, J. (2018). Benchmarks as Limits to Arbitrage: Understanding the Low-Volatility Anomaly. Financial Analysts Journal, 67(1), 40-54. doi:10.2469/faj.v67.n1.4

Baker, M., \& Wurgler, J. (2006). Investor sentiment and the cross-section of stock returns. The Journal of Finance.

Bali, T. G., Cakici, N., \& Whitelaw, R. F. (2011). Maxing out: Stocks as lotteries and the cross-section of expected returns. Journal of Financial Economics, 99(2), 427-446. doi:10.1016/j.jfineco.2010.08.014

Barberis, N., \& Thaler, R. H. (2003). A Survey of Behavioural Finance.pdf. In Handbook of Economics of Finance (Vol. 1, pp. 1053-1128).

Bassi, A., Colacito, R., \& Fulghieri, P. (2013). ' O Sole Mio: An Experimental Analysis of Weather and Risk Attitudes in Financial Decisions. Review of Financial Studies, 26(7), 1824-1852. doi:10.1093/rfs/hht004

Bekiros, S., Jlassi, M., Naoui, K., \& Uddin, G. S. (2018). Risk perception in financial markets: On the flip side. International Review of Financial Analysis, 57, 184-206. doi:10.1016/j.irfa.2018.03.005

Berger, D., \& Turtle, H. J. (2015). Sentiment bubbles. Journal of Financial Markets, 23, 59-74. doi:10.1016/j.finmar.2015.01.002

Bergsma, K., \& Jiang, D. (2016). Cultural New Year Holidays and Stock Returns around the World. Financial Management, 33.

Bijl, L., Kringhaug, G., Molnár, P., \& Sandvik, E. (2016). Google searches and stock returns. International Review of Financial Analysis, 45, 150-156. doi:10.1016/j.irfa.2016.03.015

Black, F., Jensen, M. C., \& Myron, S. (1972). The capital asset pricing model: Some empirical tests. Studies in the Theory of Capital Markets.

Blau, B. M. (2018). Price Clustering and Investor Sentiment. Journal of Behavioral Finance, 20(1), 19-30. doi:10.1080/15427560.2018.1431887

Bley, J., \& Saad, M. (2010). Cross-cultural differences in seasonality. International Review of Financial Analysis, 19(4), 306312. doi:10.1016/j.irfa.2010.08.004

Bodnaruk, A., \& Simonov, A. (2015). Do financial experts make better investment decisions? Journal of Financial Intermediation, 24(4), 514-536. doi:10.1016/j.jfi.2014.09.001

Bohl, M. T., Branger, N., \& Trede, M. (2017). The case for herding is stronger than you think. Journal of Banking \& Finance, 85, 30-40. doi:10.1016/j.jbankfin.2017.08.006

Bohl, M. T., \& Salm, C. A. (2009). The Other January Effect: international evidence. The European Journal of Finance, 16(2), 173-182. doi:10.1080/13518470903037953

Boyd, N. E., Büyükşahin, B., Haigh, M. S., \& Harris, J. H. (2016). The Prevalence, Sources, and Effects of Herding. Journal of Futures Markets, 36(7), 671-694. doi:10.1002/fut.21756

Braga, R., \& Fávero, L. P. L. (2017). Disposition Effect and Tolerance to Losses in Stock Investment Decisions: An Experimental Study. Journal of Behavioral Finance, 18(3), 271-280. doi:10.1080/15427560.2017.1308946

Brav, A., Heaton, J. B., \& Li, S. (2010). The Limits of the Limits of Arbitrage. Review of Finance, 14(1), 157-187. doi:10.1093/rof/rfp018

Brown, J. R., Farrell, A. M., \& Weisbenner, S. J. (2016). Decision-making approaches and the propensity to default: Evidence and implications. Journal of Financial Economics, 121(3), 477-495. doi:10.1016/j.jfineco.2016.05.010 
Carretta, A., Farina, V., Martelli, D., Fiordelisi, F., \& Schwizer, P. (2011). The Impact of Corporate Governance Press News on Stock Market Returns. European Financial Management, 17(1), 100-119. doi:10.1111/j.1468-036X.2010.00548.x

Cecchini, M., Bajo, E., Russo, P. M., \& Sobrero, M. (2019). Individual Differences in the Disposition Effect. Journal of Behavioral Finance, 20(1), 107-126. doi:10.1080/15427560.2018.1492579

Chahine, S., Mansi, S., \& Mazboudi, M. (2015). Media news and earnings management prior to equity offerings. Journal of Corporate Finance, 35, 177-195. doi:10.1016/j.jcorpfin.2015.09.002

Chang, C., Cheng, L.-j., \& Fuh, C.-d. (2013). The Pricing of Risk and Sentiment: A Study of Executive Stock Options. Financial Management, 21.

Chang, T. Y., Solomon, D. H., \& Westerfield, M. M. (2016). Looking for Someone to Blame: Delegation, Cognitive Dissonance, and the Disposition Effect. The Journal of Finance, 71(1), 267-302. doi:10.1111/jofi.12311

Chau, F., Deesomsak, R., \& Koutmos, D. (2016). Does investor sentiment really matter? International Review of Financial Analysis, 48, 221-232. doi:10.1016/j.irfa.2016.10.003

Chen, T. (2019). Country herding in the global market. Journal of Behavioral Finance, 21(2), 174-185. doi:10.1080/15427560.2019.1663852

Chen, Z., \& Daves, P. R. (2018). The January sentiment effect in the U.S. stock market. International Review of Financial Analysis, 59, 94-104. doi:10.1016/j.irfa.2018.07.008

Cheng, P. Y. K. (2014). Decision Utility and Anticipated Discrete Emotions: An Investment Decision Model. Journal of Behavioral Finance, 15(2), 99-108. doi:10.1080/15427560.2014.908885

Cheng, T. Y., Lee, C. I., \& Lin, C. H. (2013). An examination of the relationship between the disposition effect and gender, age, the traded security, and bull-bear market conditions. Journal of Empirical Finance, 21, $195-213$. doi:10.1016/j.jempfin.2013.01.003

Chou, P.-H., Huang, T.-Y., \& Yang, H.-J. (2013). Arbitrage risk and the turnover anomaly. Journal of Banking \& Finance, 37(11), 4172-4182. doi:10.1016/j.jbankfin.2013.07.011

Christoffersen, J., \& Stæhr, S. (2019). Individual risk tolerance and herding behaviors in financial forecasts. European Financial Management, 25(5), 1348-1377. doi:10.1111/eufm.12231

Chuang, W.-I., \& Susmel, R. (2011). Who is the more overconfident trader? Individual vs. instituational investors. Journal of Banking \& Finance, 35, 19. doi:10.1016/j.jbankfin.2010.11.013

Chue, T. K., Gul, F. A., \& Mian, G. M. (2019). Aggregate investor sentiment and stock return synchronicity. Journal of Banking \& Finance, 108. doi:10.1016/j.jbankfin.2019.105628

Cohen, G., \& Kudryavtsev, A. (2012). Investor Rationality and Financial Decisions. Journal of Behavioral Finance, 13(1), 1116. doi:10.1080/15427560.2012.653020

Cronqvist, H., \& Siegel, S. (2014). The Genetics of Investment Biases. Journal of Financial Economics, 113(2).

Dasgupta, A., Prat, A., \& Verardo, M. (2011). The Price Impact of Instituational Herding. The Review of Financial Studies, 24, 35. doi:10.1093/rfs/hhq137

De Long, J. B., Shleifer, A., Summers, L., H., \& Waldmann, R. J. (1990). Noise Trader Risk in Financial Markets. Journal of Political Economy, 98, 36.

Deaves, R., Lüders, E., \& Luo, G. Y. (2009). An Experimental Test of the Impact of Overconfidence and Gender on Trading Activity. Review of Finance, 13(3), 555-575. doi:10.1093/rof/rfn023

DeLisle, R. J., Diavatopoulos, D., Fodor, A., \& Krieger, K. (2017). Anchoring and Probability Weighting in Option Prices. Journal of Futures Markets, 37(6). doi:doi.org/10.1002/fut.21833

DeVault, L., Sias, R., \& Starks, L. (2019). Sentiment Metrics and Investor Demand. The Journal of Finance, 74(2), 985-1024. doi:10.1111/jofi.12754

Dimpfl, T., \& Jank, S. (2016). Can Internet Search Queries Help to Predict Stock Market Volatility? European Financial Management, 22(2), 171-192. doi:10.1111/eufm.12058

Dong, F., \& Wilson, S. D. (2018). Does High Stock Price Synchronicity Always Hurt Mutual Fund Industry? Sentiment Matters. Journal of Behavioral Finance, 20(1), 73-80. doi:10.1080/15427560.2018.1459623

Drehmann, M., Oechssler, J., \& Roider, A. (2005). Herding and Contrarian Behavior in Financial Markets: An Internet Experiment. American Economic Review, 95(5).

$\mathrm{Du}, \mathrm{D} .$, \& Hu, O. (2017). The sentiment premium and macroeconomic announcements. Review of Quantitative Finance and Accounting, 50(1), 207-237. doi:10.1007/s11156-017-0628-y

Duong, C., Pescetto, G., \& Santamaria, D. (2012). How value-glamour investors use financial information: UK evidence of investors' confirmation bias. The European Journal of Finance, 20(6), 524-549. doi:10.1080/1351847x.2012.722117

Durand, R. B., Fung, L., \& Limkriangkrai, M. (2019). Myopic Loss Aversion, Personality, and Gender. Journal of Behavioral Finance, 20(3), 339-353. doi:10.1080/15427560.2018.1511562

Edelen, R. M., Marcus, A. J., \& Tehranian, H. (2018). Relative Sentiment and Stock Returns. Financial Analysts Journal, 66(4), 20-32. doi:10.2469/faj.v66.n4.2

Elliot, W. B., Rennekamp, K. M., \& White, B. J. (2017). The Paradoxical Behavioral Effects of a Directional Goal on Investors' Risk Perceptions and Valuation Judgments. Journal of Behavioral Finance, 19(3), 271-290. doi:10.1080/15427560.2018.1381961

Engelberg, J. E., \& Parsons, C. A. (2011). The Causal Impact of Media in Financial Markets. The Journal of Finance, 66, 31. 
Fama, E. F. (1970). Efficient Capital Markets: A Review of Theory and Empirical Work. The Journal of Finance, $25(2), 35$.

Fama, E. F., \& French, K. R. (1992). The Cross-Section of Expected Stock Returns. The Journal of Finance, $47(2), 39$.

Fan, R., Talavera, O., \& Tran, V. (2019). Social media bots and stock markets. European Financial Management. doi:10.1111/eufm.12245

Ferris, S. P., Haugen, R. A., \& Makhija, A. K. (1988). Predicting Contemporary Volume with Historic Volume at Differential Price Levels: Evidence Supporting the Disposition Effect. The Journal of Finance, 43(3), 21.

Fiore, C., \& Saha, A. (2015). A Tale of Two Anomalies: Higher Returns of Low-Risk Stocks and Return Seasonality. The Financial Review, 50, 17.

Fong, W. M. (2013). Risk Preferences, Investor Sentiment and Lottery Stocks: A Stochastic Dominance Approach. Journal of Behavioral Finance, 14(1), 42-52. doi:10.1080/15427560.2013.759579

Fong, W. M., \& Toh, B. (2014). Investor sentiment and the MAX effect. Journal of Banking \& Finance, 46, $190-201$. doi:10.1016/j.jbankfin.2014.05.006

Frydman, C., Barberis, N., Camerer, C., Bossaerts, P., \& Rangel, A. (2014). Using Neural Data to Test A Theory of Investor Behavior: An Application to Realization Utility. The Journal of Finance, 69(2), 907-946. doi:10.1111/jofi.12126

Galariotis, E. C., Holmes, P., Kallinterakis, V., \& Ma, X. S. (2014). Market states, expectations, sentiment and momentum: How naive are investors? International Review of Financial Analysis, 32, 1-12. doi:10.1016/j.irfa.2013.12.004

Gębka, B., \& Wohar, M. E. (2013). International herding: Does it differ across sectors? Journal of International Financial Markets, Institutions and Money, 23, 55-84. doi:10.1016/j.intfin.2012.09.003

Gerlach, J. R. (2010). Daylight and Investor Sentiment: A Second Look at Two Stock Market Behavioral Anomalies. The Journal of Financial Research, 33, 34.

Goetzmann, W. N., Kim, D., Kumar, A., \& Wang, Q. (2015). Weather-Induced Mood, Institutional Investors, and Stock Returns. Review of Financial Studies, 28(1), 73-111. doi:10.1093/rfs/hhu063

Gokhale, J., Tremblay, C. H., \& Tremblay, V. J. (2015). Misvaluation and Behavioral Bias in Financial Markets. Journal of Behavioral Finance, 16(4), 344-356. doi:10.1080/15427560.2015.1095756

Gregory-Allen, R., Jacobsen, B., \& Marquering, W. (2010). The Daylight Saving Time Anomaly in Stock Returns: Fact or Fiction? The Journal of Financial Research, 33, 25.

Grinblatt, M., \& Keloharju, M. (2009). Sensation Seeking, Overconfidence and Trading Activity. The Journal of Finance, 64, 30 .

Gromb, D., \& Vayanos, D. (2010). Limits of Arbitrage. Annual Review of Financial Economics, $2(1), 251-275$. doi:10.1146/annurev-financial-073009-104107

Haggard, K. S., \& Witte, H. D. (2010). The Halloween effect: Trick or treat? International Review of Financial Analysis, 19(5), 379-387. doi:10.1016/j.irfa.2010.10.001

Hao, Y., Chou, R. K., Ko, K.-C., \& Yang, N.-T. (2018). The 52-week high, momentum, and investor sentiment. International Review of Financial Analysis, 57, 167-183. doi:10.1016/j.irfa.2018.01.014

Hartzmark, S. M. (2015). The Worst, the Best, Ignoring All the Rest: The Rank Effect and Trading Behavior. The Review of Financial Studies, 28(4), 1024-1059. doi:10.1093/rfs/hhu079

Hens, T., \& Vlcek, M. (2011). Does Prospect Theory Explain the Disposition Effect? Journal of Behavioral Finance, 12(3), 141157. doi:10.1080/15427560.2011.601976

Heston, S. L., \& Sadka, R. (2010). Seasonality in the Cross Section of Stock Returns: The International Evidence. Journal of Financial and Quantitative Analysis, 45(5), 1133-1160. doi:10.1017/s0022109010000451

Hilliard, J., Narayanasamy, A., \& Zhang, S. (2019). The Role of Market Sentiment in Asset Allocations and Stock Returns. Journal of Behavioral Finance, 1-19. doi:10.1080/15427560.2019.1663854

Hombert, J., \& Thesmar, D. (2014). Overcoming limits of arbitrage: Theory and evidence. Journal of Financial Economics, 111(1), 26-44. doi:10.1016/j.jfineco.2013.09.003

Huang, D., Jiang, F., Tu, J., \& Zhou, G. (2015). Investor Sentiment Aligned: A Powerful Predictor of Stock Returns. Review of Financial Studies, 28(3), 791-837. doi:10.1093/rfs/hhu080

Huang, Z., Heian, J. B., \& Zhang, T. (2011). Differences of Opinion, OVerconfidence, and the High-Volume Premium. The Journal of Financial Research, 34, 25.

Huber, J., Palan, S., \& Zeisberger, S. (2019). Does investor risk perception drive asset prices in markets? Experimental evidence. Journal of Banking \& Finance, 108. doi:10.1016/j.jbankfin.2019.105635

Hung, W., \& Yang, J. J. (2018). The MAX effect: Lottery stocks with price limits and limits to arbitrage. Journal of Financial Markets, 41, 77-91. doi:10.1016/j.finmar.2018.07.003

Huynh, T. D., \& Smith, D. R. (2017). Stock Price Reaction to News: The Joint Effect of Tone and Attention on Momentum. Journal of Behavioral Finance, 18(3), 304-328. doi:10.1080/15427560.2017.1339190

Hwang, B.-H. (2011). Country-specific sentiment and security prices ‘. Journal of Financial Economics, 100(2), 382-401. doi:10.1016/j.jfineco.2010.10.020

Hwang, S., \& Salmon, M. (2004). Market stress and herding. Journal of Empirical Finance, 11(4), 585-616. doi:10.1016/j.jempfin.2004.04.003

Itzkowitz, J., Itzkowitz, J., \& Rothbort, S. (2016). ABCs of Trading: Behavioral Biases affect Stock Turnover and Value *. Review of Finance, 20(2), 663-692. doi:10.1093/rof/rfv012 
Jacobsen, B., \& Visaltanachoti, N. (2009). The Halloween Effect in U.S. Sectors. The Financial Review, 44, 23.

Jacoby, G., \& Liao, R. C. (2012). Price discovery and sentiment. International Review of Financial Analysis, $21,108-118$. doi:10.1016/j.irfa.2011.09.005

Kaplanski, G., \& Levy, H. (2010). Sentiment and stock prices: The case of aviation disasters. Journal of Financial Economics, 95(2), 174-201. doi:10.1016/j.jfineco.2009.10.002

Kariofyllas, S., Philippas, D., \& Siriopoulos, C. (2017). Cognitive biases in investors' behaviour under stress: Evidence from the London Stock Exchange. International Review of Financial Analysis, 54, 54-62. doi:10.1016/j.irfa.2017.09.003

Kaustia, M., \& Rantapuska, E. (2016). Does mood affect trading behavior? Journal of Financial Markets, $29,1-26$. doi:10.1016/j.finmar.2015.08.001

Keiber, K. L., \& Samyschew, H. (2018). The pricing of sentiment risk in European stock markets. The European Journal of Finance, 25(3), 279-302. doi:10.1080/1351847x.2018.1521340

Keloharju, M., Linnainmaa, J. T., \& Nyberg, P. (2016). Return Seasonalities. The Journal of Finance, 71(4), 1557-1590. doi:10.1111/jofi.12398

Kim, B., \& Suh, S. (2018). Sentiment-based momentum strategy. International Review of Financial Analysis, 58, 52-68. doi:10.1016/j.irfa.2018.04.004

Kim, J. H. (2017). Stock returns and investors' mood: Good day sunshine or spurious correlation? International Review of Financial Analysis, 52, 94-103. doi:10.1016/j.irfa.2017.05.004

Korniotis, G. M., \& Kumar, A. (2011). Do Behavioral Biases Adversely Affect the Macro-economy? Review of Financial Studies, 24(5), 1513-1559. doi:10.1093/rfs/hhq110

Kräussl, R., \& Mirgorodskaya, E. (2016). Media, sentiment and market performance in the long run. The European Journal of Finance, 23(11), 1059-1082. doi:10.1080/1351847x.2016.1226188

Kremer, S., \& Nautz, D. (2013). Causes and consequences of short-term institutional herding. Journal of Banking \& Finance, 37(5), 1676-1686. doi:10.1016/j.jbankfin.2012.12.006

Kubińska, E., Markiewicz, Ł., \& Tyszka, T. (2012). Disposition Effect Among Contrarian and Momentum Investors. Journal of Behavioral Finance, 13(3), 214-225. doi:10.1080/15427560.2012.708687

Lakonishok, J., Shleifer, A., \& Vishny, R. W. (1992). The impact of instituational trading on stock prices. Journal of Financial Economics, 32, 21.

Lam, F. Y. E. C., \& Wei, K. C. J. (2011). Limits-to-arbitrage, investment frictions, and the asset growth anomaly. Journal of Financial Economics, 102(1), 127-149. doi:10.1016/j.jfineco.2011.03.024

Lam, K., Liu, T., \& Wong, W.-K. (2012). A New Pseudo-Bayesian Model with Implications for Financial Anomalies and Investors' Behavior. Journal of Behavioral Finance, 13(2), 93-107. doi:10.1080/15427560.2012.680993

Lee, E., \& Piqueira, N. (2019). Behavioral biases of informed traders: Evidence from insider trading on the 52-week high. Journal of Empirical Finance, 52, 56-75. doi:10.1016/j.jempfin.2019.02.007

Li, F., Zhang, H., \& Zheng, D. (2018). Seasonality in the cross section of stock returns: Advanced markets versus emerging markets. Journal of Empirical Finance, 49, 263-281. doi:10.1016/j.jempfin.2018.11.001

Li, X., \& Sullivan, R. N. (2018). The Limits to Arbitrage Revisited: The Accrual and Asset Growth Anomalies. Financial Analysts Journal, 67(4), 50-66. doi:10.2469/faj.v67.n4.5

Li, X., Sullivan, R. N., \& Garcia-Feijóo, L. (2018). The Limits to Arbitrage and the Low-Volatility Anomaly. Financial Analysts Journal, 70(1), 52-63. doi:10.2469/faj.v70.n1.3

Liang, S. X. (2018). The systematic pricing of market sentiment shock. The European Journal of Finance, 24(18), 1835-1860. doi:10.1080/1351847x.2018.1491875

Ljungqvist, A., \& Qian, W. (2016). How Constraining Are Limits to Arbitrage? Review of Financial Studies, 29(8), 1975-2028. doi:10.1093/rfs/hhw028

Mangee, N. (2018). Stock Returns and the Tone of Marketplace Information: Does Context Matter? Journal of Behavioral Finance, 19(4), 396-406. doi:10.1080/15427560.2018.1405268

Marshall, B. R., \& Visaltanachoti, N. (2010). The Other January Effect: Evidence against market efficiency? Journal of Banking \& Finance, 34(10), 2413-2424. doi:10.1016/j.jbankfin.2010.03.019

McCannon, B. C., \& Peterson, J. (2015). Born for Finance? Experimental Evidence of the Impact of Finance Education. Journal of Behavioral Finance, 16(3), 199-205. doi:10.1080/15427560.2015.1064933

Meier, C., \& De Mello, L. (2019). Investor Overconfidence in Experimental Asset Markets across Market States. Journal of Behavioral Finance, 1-16. doi:10.1080/15427560.2019.1692845

Merkle, C. (2017). Financial overconfidence over time: Foresight, hindsight, and insight of investors. Journal of Banking \& Finance, 84, 68-87. doi:10.1016/j.jbankfin.2017.07.009

Meziani, A. S., \& Noma, E. (2018). A New Method of Measuring Financial Risk Aversion Using Hypothetical Investment Preferences: What Does It Say in the Case of Gender Differences? Journal of Behavioral Finance, 19(4), 450-461. doi:10.1080/15427560.2018.1431888

Muñoz Torrecillas, M. J., Yalamova, R., \& McKelvey, B. (2016). Identifying the Transition from Efficient-Market to Herding Behavior: Using a Method from Econophysics. Journal of Behavioral Finance, 17(2), 157-182. doi:10.1080/15427560.2016.1170680

Odean, T. (1998). Are Investors Reluctant to Realize Their Losses? The Journal of Finance, 53(5), 24. 
Oehler, A., Wendt, S., Wedlich, F., \& Horn, M. (2017). Investors' Personality Influences Investment Decisions: Experimental Evidence on Extraversion and Neuroticism. Journal of Behavioral Finance, 19(1), 30-48. doi:10.1080/15427560.2017.1366495

Otuteye, E., \& Siddiquee, M. (2015). Overcoming Cognitive Biases: A Heuristic for Making Value Investing Decisions. Journal of Behavioral Finance, 16(2), 10.

Peress, J. (2014). The Media and the Diffusion of Information in Financial Markets: Evidence from Newspaper Strikes. The Journal of Finance, 69(5), 2007-2043. doi:10.1111/jofi.12179

Pizzutilo, F., \& Roncone, V. (2016). Red sky at night or in the morning, to the equity market neither a delight nor a warning: the weather effect re-examined using intraday stock data. The European Journal of Finance, 23(14), 1280-1310. doi:10.1080/1351847x.2016.1151808

Reed, M. (2016). A Study of Social Network Effects on the Stock Market. Journal of Behavioral Finance, 17(4), 342-351. doi:10.1080/15427560.2016.1238371

Roider, A., \& Voskort, A. (2016). Reputational Herding in Financial Markets: A Laboratory Experiment. Journal of Behavioral Finance, 17(3), 244-266. doi:10.1080/15427560.2016.1203322

Sahi, S. K., Arora, A. P., \& Dhameja, N. (2013). An Exploratory Inquiry into the Psychological Biases in Financial Investment Behavior. Journal of Behavioral Finance, 14(2), 94-103. doi:10.1080/15427560.2013.790387

Samuelson, P. A. (1965). Proof That Properly Anticipated Prices Fluctuate Randomly. Industrial Management Review, 6(2), 9.

Savor, P. G. (2012). Stock returns after major price shocks: The impact of information. Journal of Financial Economics, 106(3), 635-659. doi:10.1016/j.jfineco.2012.06.011

Schmeling, M. (2009). Investor sentiment and stock returns: Some international evidence. Journal of Empirical Finance, 16(3), 394-408. doi:10.1016/j.jempfin.2009.01.002

Schmittmann, J. M., Pirschel, J., Meyer, S., \& Hackethal, A. (2015). The Impact of Weather on German Retail Investors*. Review of Finance, 19(3), 1143-1183. doi:10.1093/rof/rfu020

Shefrin, H., \& Statman, M. (1985). The Disposition to Sell Winners Too Early and Ride Losers Too Long: Theory and Evidence. The Journal of Finance, 40(3), 14.

Shiller, R. J. (2019). Narrative Economics: How Stories go Viral and Drive Major Economic Events. Princeton, New Jersey: Princeton University Press.

Shleifer, A., \& Vishny, R. W. (1997). The Limits of Arbitrage. The Journal of Finance, 52(1), 21. doi:10.1111/j.15406261.1997.tb03807.x

Shu, H.-C., \& Chang, J.-H. (2015). Investor Sentiment and Financial Market Volatility. Journal of Behavioral Finance, 16(3), 206-219. doi:10.1080/15427560.2015.1064930

Sibley, S. E., Wang, Y., Xing, Y., \& Zhang, X. (2016). The information content of the sentiment index. Journal of Banking \& Finance, 62, 164-179. doi:10.1016/j.jbankfin.2015.10.001

Siddiqi, H. (2019). Anchoring-Adjusted Option Pricing Models. Journal of Behavioral Finance, $20(2), 139-153$. doi:10.1080/15427560.2018.1492922

Siganos, A., Vagenas-Nanos, E., \& Verwijmeren, P. (2017). Divergence of sentiment and stock market trading. Journal of Banking \& Finance, 78, 130-141. doi:10.1016/j.jbankfin.2017.02.005

Taffler, R. (2017). Emotional finance: investment and the unconscious. The European Journal of Finance, 24(7-8), 630-653. doi:10.1080/1351847x.2017.1369445

Tranfield, D., Denyer, D., \& Smart, P. (2003). Towards a Methodology for Developing Evidence-Informed Management Knowledge by Means of Systematic Review. British Journal of Management, 14, 16.

Uhl, M. W. (2017). Emotions Matter: Sentiment and Momentum in Foreign Exchange. Journal of Behavioral Finance, 18(3), 249-257. doi:10.1080/15427560.2017.1332061

Urquhart, A., \& McGroarty, F. (2014). Calendar effects, market conditions and the Adaptive Market Hypothesis: Evidence from long-run U.S. data. International Review of Financial Analysis, 35, 154-166. doi:10.1016/j.irfa.2014.08.003

Urquhart, A., \& McGroarty, F. (2016). Are stock markets really efficient? Evidence of the adaptive market hypothesis. International Review of Financial Analysis, 47, 39-49. doi:10.1016/j.irfa.2016.06.011

Vieito, J. P., da Rocha, A. F., \& Rocha, F. T. (2015). Brain Activity of the Investor's Stock Market Financial Decision. Journal of Behavioral Finance, 16(3), 220-230. doi:10.1080/15427560.2015.1064931

von Beschwitz, B., \& Massa, M. (2015). Biased Shorts: Short sellers' Disposition Effect and Limits to Arbitrage. International Finance Discussion Paper, 2015(1147), 1-53. doi:10.17016/ifdp.2015.1147

Wang, M., Keller, C., \& Siegrist, M. (2011). The Less You Know, the More You Are Afraid of-A Survey on Risk Perceptions of Investment Products. Journal of Behavioral Finance, 12(1), 9-19. doi:10.1080/15427560.2011.548760

Wei, J. (2018). Behavioral biases in the corporate bond market. Journal of Empirical Finance, 46, 34-55. doi:10.1016/j.jempfin.2017.12.003

Yan, Z., \& Zhao, Y. (2018). When Two Anomalies Meet: The Post-Earnings Announcement Drift and the Value-Glamour Anomaly. Financial Analysts Journal, 67(6), 46-60. doi:10.2469/faj.v67.n6.3

Yang, A. S., \& Wu, M.-L. (2011). Exploring the relationship between investor sentiment and price volatility. Quantitative Finance, 11(6), 955-965. doi:10.1080/14697688.2010.507214 
Yang, L., Goh, J., \& Chiyachantana, C. (2016). Valuation uncertainty, market sentiment and the informativeness of institutional trades. Journal of Banking \& Finance, 72, 81-98. doi:10.1016/j.jbankfin.2016.07.009

Zhang, Y., Swanson, P. E., \& Prombutr, W. (2012). Measing Effects on Stock Returns of Sentiment Indexes Created from Stock Message Boards. The Journal of Financial Research, 35, 36.

Zhou, R. T., \& Lai, R. N. (2009). Herding and information based trading. Journal of Empirical Finance, 16(3), $388-393$. doi:10.1016/j.jempfin.2009.01.004

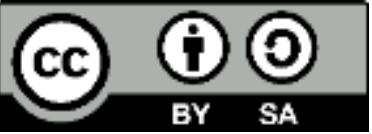

(C) 2021 by the authors. Licensee ACRN Publishing, Austria, Editor in Chief Prof. Dr. Othmar M. Lehner. This article is an open access article distributed under the terms and conditions of the Creative Commons Attribution (CC BY SA) license (https://creativecommons.org/licenses/by-sa/4.0/) 


\section{APPENDIX}

Table Overview of selected journals and findings per category

\begin{tabular}{|c|c|c|c|c|c|c|c|c|c|}
\hline Journal & Datenbank & $\begin{array}{c}\text { Behavioral } \\
\text { Finance }\end{array}$ & $\begin{array}{l}\text { Investors } \\
\text { Behavior }\end{array}$ & $\begin{array}{c}\text { Market } \\
\text { Anomalies }\end{array}$ & $\begin{array}{l}\text { Limits to } \\
\text { Arbitrage }\end{array}$ & $\begin{array}{c}\text { Behavioral } \\
\text { Biases }\end{array}$ & $\begin{array}{l}\text { Total (incl. } \\
\text { Duplicates) }\end{array}$ & $\begin{array}{l}\text { Total (excl. } \\
\text { Duplicates) }\end{array}$ & $\begin{array}{c}\text { SJR } \\
\text { Impact } \\
\text { Factor } \\
\end{array}$ \\
\hline Journal of Banking and Finance & 0378-4266 Scopus & 116 & 134 & 70 & 12 & 13 & 345 & 293 & 1.599 \\
\hline Journal of Behavioral Finance & 1542-7579 Scopus & 240 & 118 & 19 & 1 & 34 & 412 & 262 & 0.581 \\
\hline Journal of Financial Economics & 0304-405XScopus & 98 & 71 & 0 & 19 & 9 & 197 & 171 & 13.636 \\
\hline International Review of Financial Analysis & 1057-5219 Scopus & 45 & 68 & 45 & 2 & 4 & 164 & 135 & 0.782 \\
\hline Journal of Empirical Finance & 0927-5398 Scopus & 66 & 38 & 36 & 4 & 6 & 150 & 127 & 1.072 \\
\hline Quantitative Finance & 1469-7688 Scopus & 59 & 51 & 29 & 5 & 5 & 149 & 117 & 0.769 \\
\hline European Journal of Finance & 1351-847X Scopus & 31 & 45 & 31 & 2 & 9 & 118 & 96 & 0.533 \\
\hline Review of Financial Studies & 0893-9454 Scopus & 26 & 36 & 38 & 7 & 3 & 110 & 94 & 12.516 \\
\hline Journal of International Financial Markets Institutions and Money & 1042-4431 Scopus & 22 & 52 & 21 & 2 & 3 & 100 & 93 & 0.956 \\
\hline Review of Quantitative Finance and Accounting & 0924-865XScopus & 18 & 48 & 28 & 2 & 6 & 102 & 86 & 0.650 \\
\hline Journal of International Money and Finance & 0261-5606 Scopus & 34 & 34 & 15 & 4 & 2 & 89 & 85 & 1.370 \\
\hline Journal of Finance & 0022-1082 Scopus & 35 & 37 & 23 & 3 & 5 & 103 & 84 & 17.973 \\
\hline Journal of Financial and Quantitative Analysis & 0022-1090 Scopus & 27 & 32 & 24 & 3 & 3 & 89 & 79 & 3.986 \\
\hline Journal of Corporate Finance & 0929-1199 Scopus & 13 & 46 & 17 & 0 & 2 & 78 & 72 & 1.748 \\
\hline Journal of Financial Markets & 1386-4181 Scopus & 23 & 33 & 18 & 9 & 3 & 86 & 72 & 1.033 \\
\hline Journal of Futures Markets & 0270-7314 Scopus & 20 & 24 & 15 & 9 & 3 & 71 & 66 & 0.829 \\
\hline Review of Finance (formerly European Finance Review) & 1572-3097 Scopus & 20 & 27 & 15 & 5 & 4 & 71 & 62 & 3.465 \\
\hline European Financial Management & 1354-7798 Scopus & 14 & 28 & 14 & 1 & 4 & 61 & 57 & 0.618 \\
\hline Journal of Real Estate Finance and Economics & 0895-5638 Scopus & 16 & 24 & 14 & 0 & 2 & 56 & 53 & 0.885 \\
\hline International Journal of Finance and Economics & 1076-9307 Scopus & 13 & 22 & 12 & 1 & 12 & 60 & 41 & 0.514 \\
\hline
\end{tabular}


Financial Review

\section{Financial Management}

Corporate Governance An International Review Journal of Financial Research

Journal of Money, Credit and Banking

Journal of Financial Econometrics

Financial Analysts Journal

Journal of Financial Intermediation

Journal of Financial Stability

Journal of Financial Services Research

Insurance, Mathematics and Economics

Mathematical Finance

Annual Review of Financial Economics

Journal of Risk and Insurance

Financial Markets, Institutions and Instruments

Finance and Stochastics

Review of Asset Pricing Studies

$\begin{array}{lcccccccc}\text { 0732-8516 Scopus } & 17 & 14 & 11 & 2 & 4 & 48 & 39 & 0.567 \\ \text { 0046-3892 Scopus } & 6 & 18 & 10 & 2 & 0 & 36 & 33 & 1.262 \\ \text { 0964-8410 Scopus } & 3 & 22 & 3 & 0 & 2 & 30 & 28 & 1.432 \\ \text { 0270-2592 Scopus } & 5 & 16 & 9 & 1 & 0 & 31 & 28 & 0.760 \\ \text { 0022-2879 Scopus } & 13 & 7 & 6 & 0 & 0 & 26 & 26 & 2.357 \\ \text { 1479-8409 Scopus } & 17 & 0 & 4 & 1 & 0 & 22 & 22 & 2.282 \\ \text { 0015-198X Scopus } & 6 & 3 & 12 & 3 & 0 & 24 & 21 & 0.920 \\ \text { 1042-9573 Scopus } & 4 & 10 & 7 & 2 & 1 & 24 & 21 & 3.514 \\ \text { 1572-3089 Scopus } & 5 & 10 & 5 & 0 & 4 & 24 & 20 & 1.488 \\ \text { 0920-8550 Scopus } & 2 & 13 & 3 & 1 & 0 & 19 & 19 & 0.965 \\ \text { 0167-6687 Scopus } & 4 & 6 & 4 & 0 & 0 & 14 & 14 & 0.949 \\ \text { 0960-1627 Scopus } & 5 & 6 & 1 & 2 & 0 & 14 & 14 & 2.834 \\ \text { 1941-1367 Scopus } & 5 & 6 & 2 & 2 & 0 & 15 & 12 & 4.584 \\ \text { 0022-4367 Scopus } & 2 & 2 & 5 & 0 & 1 & 10 & 10 & 1.197 \\ 0963-8008 \text { Scopus } & 3 & 5 & 0 & 0 & 0 & 8 & 8 & 1.376 \\ 0949-2984 \text { Scopus } & 1 & 2 & 0 & 4 & 0 & 7 & 7 & 2.254 \\ \text { 2045-9939 Scopus } & 2 & 2 & 2 & 0 & 0 & 6 & 5 & \text { no IF }\end{array}$

